Published in final edited form as:

J Org Chem. 2019 June 07; 84(11): 6697-6708. doi:10.1021/acs.joc.9b00385.

\title{
9-Azido-9-deoxy-2,3-difluorosialic Acid as A Subnanomolar Inhibitor Against Bacterial Sialidases
}

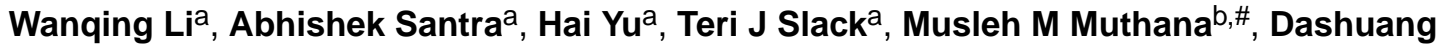 \\ Shi $^{\mathrm{c}}$, Yang Liu ${ }^{\mathrm{b}, \#}, \mathrm{Xi} \mathrm{Chen}^{\mathrm{a},{ }^{*}}$ \\ aDepartment of Chemistry, University of California-Davis, One Shields Avenue, Davis, CA 95616, \\ USA \\ beenter for Cancer and Immunology Research, Children's National Medical Center, 111 Michigan \\ Ave, NW, Washington DC 20012, USA \\ 'Center for Genetic Medicine Research, Children's National Medical Center, 111 Michigan Ave, \\ NW, Washington DC 20012, USA
}

\section{Abstract}

A library of 2(e),3(a/e)-difluorosialic acids and their C-5 and/or C-9 derivatives were chemoenzymatically synthesized. Pasteurella multocida sialic acid aldolase (PmAldolase), but not its Escherichia coli homolog (EcAldolase), was found to catalyze the formation of C5-azido analog of 3-fluoro(equatorial)-sialic acid. In comparison, both PmAldolase and EcAldolase could catalyze the synthesis of 3-fluoro (axial or equatorial)-sialic acids and their C-9 analogs although PmAldolase was generally more efficient. The chemoenzymatically synthesized 3-fluoro (axial or equatorial)-sialic acid analogs were purified and chemically derivatized to form desired difluorosialic acids and derivatives. Inhibition studies against several bacterial sialidases and a recombinant human cytosolic sialidase hNEU2 indicated that sialidase inhibition was affected by the C-3 fluorine stereochemistry and derivatization at C-5 and/or C-9 of the inhibitor. Opposite to that observed for influenza A virus sialidases and hNEU2, compounds with an axial fluorine at C-3 were better inhibitors (up to 100-fold) against bacterial sialidases compared to their 3Fequatorial counterparts. While C-5-modified compounds were less efficient anti-bacterial sialidase inhibitors, 9-N 3 -modified 2,3-difluoro-Neu5Ac showed increased inhibitory activity against bacterial sialidases. 9-Azido-9-deoxy-2-equatorial-3-axial-difluoro- $N$-acetylneuraminic acid $\left(2 e 3 a \mathrm{DFNeu} 5 \mathrm{Ac} 9 \mathrm{~N}_{3}\right)$ was identified as an effective inhibitor with a long effective duration selectively against pathogenic bacterial sialidases from Clostridium perfringens (CpNanI) and $V$. cholerae.

\footnotetext{
*Corresponding Author: xiichen@ucdavis.edu.

\#Present Addresses: Division of Immunotherapy, Institute of Human Virology, University of Maryland, Baltimore, MD 21201, United States

Supporting Information

The Supporting Information is available free of charge on the ACS Publications website.

Sialidase inhibition IC 50 plots for compounds 1-6 (Figure S1), time course study results for sialidase deactivation and reactivation in the presence or the absence of a covalent inhibitor (1 or 3-5) (Figure S2), and NMR spectra of compounds (1-6 and 11-13) (PDF).

Notes

The authors declare no competing financial interest.
} 


\section{Graphical abstract}

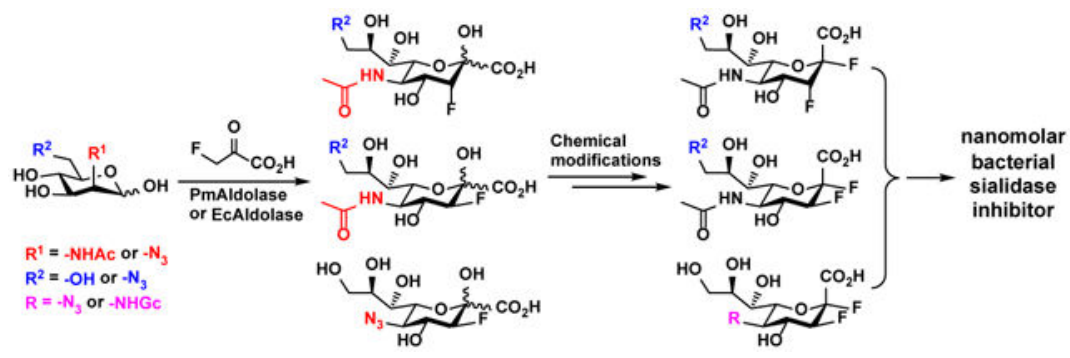

\section{Keywords}

Carbohydrate; Difluorosialic acid; Neuraminidase; Sialidase; Sialidase inhibitor

\section{INTRODUCTION}

Sialic acids are a family of negatively charged monosaccharides with a nine-carbon backbone. They play important roles in human homeostasis and pathological processes. ${ }^{1}$ The level of sialic acid on cell surface is regulated by the functions of sialyltransferases, sialidases, and the availability of sialyltransferase donor substrates cytidine-5'monophosphate sialic acids (CMP-Sia). ${ }^{1-3}$ Sialidases or neuraminidases (EC 3.2.1.18) are key enzymes for the catabolism of sialic acid-containing oligosaccharides or glycoconjugates, in which they catalyze the cleavage of terminal sialic acids. ${ }^{2}$ Sialidases found in bacteria, viruses, fungi, and mammals have differences in their primary sequences, but share a common catalytic domain. ${ }^{4}$

Bacterial sialidases play diverse roles including a nutritional function for providing bacteria with carbon and energy sources, serving as virulence factors during bacterial pathogenesis, and immunomodulatory effects. ${ }^{5-9}$ For example, Streptococcus pneumoniae ${ }^{10}$ and Tannerella forsythia ${ }^{11}$ produce sialidases which release sialic acids as bacterial carbon and energy sources. ${ }^{12}$ In addition, Streptococcus pneumoniae sialidase SpNanA is essential for pathogenesis of Streptococcus pneumoniae, which causes respiratory-tract infections, pneumonia, otitis media, bacteremia, sepsis, and meningitis, etc. ${ }^{13}$ Clostridium perfringens sialidase may facilitate the infection of this Gram-positive pathogenic bacterium which causes histotoxic infections and intestinal diseases. ${ }^{14}$ Therefore, bacterial sialidases are attractive targets for drug development.

The effort of protein crystal structure-based rational design has successfully identified several sialidase inhibitors as effective anti-influenza A virus therapeutics, including Zanamivir (Relenza, GlaxoSmithKline), ${ }^{15}$ Oseltamivir (Tamiflu, Gilead/Roche), ${ }^{15,16}$ Peramivir (Rapivab, BioCryst), ${ }^{16-20}$ Laninamivir, ${ }^{21}$ and TCN-032. ${ }^{22,23}$ Crystal structures of an increasing number of bacterial sialidases are becoming available and an improved understanding of their mechanisms has been achieved, providing a great opportunity for designing inhibitors selectively against bacterial sialidases. ${ }^{24-26}$ Indeed, sialidase inhibitors have shown to protect mice against bacterial sepsis in an animal model. ${ }^{27}$ 
In addition to inhibitors designed based on sialidase transition state analog 2-deoxy-2,3didehydro- $N$-acetylneuraminic acid (Neu5Ac2en or DANA) $)^{24,27-29}$ or sialidase product analog, ${ }^{25,30}$ difluorosialic acids were developed as a new class of mechanism-based sialidase inhibitors. ${ }^{31-34}$ The addition of an electronegative fluorine atom as a good leaving group at $\mathrm{C}-2$ of sialic acids was shown to allow the formation of a covalent bond between the sialic acid and the sialidase. Adding another fluorine at C-3 of sialic acid was shown to destabilize the oxocarbenium-like transition state, ${ }^{35,36}$ slow down the cleavage of the glycosyl-enzyme covalent bond, thus trap the intermediate. ${ }^{31-33,37-39}$ Indeed, the designed difluorocompounds were demonstrated to form glycosyl-enzyme intermediates with several parasite trans-sialidases, some bacterial sialidases, and human cytosolic sialidase hNEU2 by nuclear magnetic resonance (NMR) spectroscopy, mass spectrometry (MS), and/or X-ray crystal structures. ${ }^{31-33,38,39}$ Influenza A virus neuraminidases were shown to follow the same mechanism involving the formation of a glycosyl-enzyme intermediate. ${ }^{34}$ 2(equatorial), 3(equatorial)-Difluorosialic acid with a C4-guanidinium group was proven to have superior in vitro anti-influenza A virus efficacy compared to its $\mathrm{C} 4$-ammonium or its 2(equatorial), 3(axial)-difluorosialic acid counterpart with an inhibition efficacy comparable to that of Zanamivir. ${ }^{34}$

We showed previously that derivatization of Neu5Ac2en-based sialidase inhibitor at carbon 9 and carbon 5 significantly affected its selectivity against different sialidases. ${ }^{26,40} \mathrm{We}$ aimed to introduce selectivity to 2,3-difluoro sialic acid-based sialidase inhibitors by exploring modifications at C-5 and/or C-9 as well as varying C-3 fluorine stereochemistry (axial or equatorial). As shown below, an effective inhibitor with inhibition values in a low nanomolar range against bacterial sialidases including those from Streptococcus pneumoniae (SpNanA), Clostridium perfringens (CpNanI), and Arthrobacter ureafaciens is identified. The inhibitor also has a long effective duration against pathogenic bacterial sialidases from $V$. cholerae (with a reactivation half-life of $>24$ hours) and Clostridium perfringens (CpNanI) (with a reactivation half-life of $>60$ hours). The compound can be explored to further improve its property for potential application as useful chemical glycobiological tools and/or strategies to combat bacterial infection or host immune-regulation.

\section{RESULTS AND DISCUSSION}

Synthesis of 2,3-Difluorosialic Acids and Analogs. A library of 2(equatorial),3(equatorial/ axial)-difluoro sialic acids and analogs (Figure 1) were designed and synthesized, which include a C-3 fluorine (equatorial) with or without modification on C-5 or C-9 (Compounds 1-4), or a C-3 fluorine (axial) with or without modification on C-9 (Compounds 5-6).

$2 e 3 e D F N e u 5 A c(\mathbf{1})$ and $2 e 3 a D F N e u 5 A c(5)$, as well as $2 e 3 e D F N e u 5 A c 9 N_{3}(2)$ and $2 e 3 a \mathrm{DFNeu} 5 \mathrm{Ac} 9 \mathrm{~N}_{3}(\mathbf{6})$ were synthesize to address the question whether C-3 fluorine stereochemistry would influence the inhibition of sialidases. $2 e 3 e \operatorname{DFNeu}_{3} \mathrm{~N}_{3}(\mathbf{3})$ and $2 e 3 \mathrm{eDFNeu} 5 \mathrm{Gc}(\mathbf{4})$ were produced to allow the comparison with $2 \mathrm{e} 3 \mathrm{eDFNeu} 5 \mathrm{Ac}(\mathbf{1})$ to study the effect of C-5 modification. The comparison of $2 e 3 e D F N e u 5 A c 9 N_{3}(2)$ and $2 e 3 e$ DFNeu $5 \mathrm{Ac}(\mathbf{1})$, as well as $2 e 3 \mathrm{aDFNeu} 5 \mathrm{Ac} 9 \mathrm{~N}_{3}(\mathbf{6})$ and $2 e 3 \mathrm{aDFNeu} 5 \mathrm{Ac}(\mathbf{5})$ can lead to the understanding of the effect of modifications at C-9. In addition, comparison with results 
from previous reported inhibition studies using C-5 and C-9 of Neu5Ac2en ${ }^{26}$ would gain insights for the preferred type of inhibitors against different bacterial sialidases.

As shown in Scheme 1, an efficient chemoenzymatic method similar to a strategy reported previously ${ }^{32,33,41}$ was used to synthesize target difluoro-compounds. To obtain $2 e 3 e \mathrm{DFNeu} 5 \mathrm{Ac}$ (1) and 2e3aDFNeu5Ac (5), 3-deoxy-3-fluoro-Neu5Ac intermediates $3 \mathrm{~F}(e) \mathrm{Neu} 5 \mathrm{Ac}(\mathbf{8 a})$ and $3 \mathrm{~F}($ a) Neu5Ac $(\mathbf{8 b})$ with a C-3 fluorine at either equatorial or axial position were synthesized by incubating sodium 3-fluoro-pyruvate with $\mathrm{N}$ acetylmannosamine (7a) (Scheme 1A) in a Tris- $\mathrm{HCl}$ buffer $(100 \mathrm{mM}, \mathrm{pH}=7.5)$ at $37^{\circ} \mathrm{C}$ for overnight in the presence of Pasteurella multocida sialic acid aldolase (PmAldolase) ${ }^{42}$ or Escherichia coli sialic acid aldolase (EcAldolase). ${ }^{43}$ A mixture of $3 \mathrm{~F}(e) N e u 5 A c$ and $3 \mathrm{~F}($ a)Neu5Ac $(\mathbf{8 a}, \mathbf{8 b})$ diastereomers with a ratio close to 4:6 was obtained when either PmAldolase or EcAldolase was used. The diastereomers were readily purified and separated from each other by a simple silica gel column chromatography. Further modifications including esterification and per- $O$-acetylation followed by selective deprotection of the anomeric site using hydrazine acetate yielded hemiacetals $\mathbf{9 a}$ and $\mathbf{9 b}$, respectively. These were treated with diethylaminosulfur trifluoride (DAST) to introduce the C-2 equatorial fluorine for the formation of $\mathbf{1 0 a}$ and $\mathbf{1 0 b}$ respectively. Full deprotection was achieved by saponification followed by the treatment with aqueous sodium hydroxide to produce compounds $\mathbf{1}$ and $\mathbf{5}$ with yields comparable to those reported previously. ${ }^{33}$

To synthesize 9-azido-9-deoxy derivatives $2 \mathrm{e} 3 \mathrm{eDFNeu} 5 \mathrm{Ac} 9 \mathrm{~N}_{3}$ (2) and $2 \mathrm{e} 3 \mathrm{aDFNeu} 5 \mathrm{Ac} 9 \mathrm{~N}_{3}$ (6), 6-azido-6-deoxy- $N$-acetylmannosamine (ManNAc6 $\mathrm{N}_{3}, 7 \mathbf{b}$ ) ${ }^{44}$ was used as a starting material to react with sodium 3-fluoro-pyruvate using either PmAldolase or EcAldolase to form a mixture of $3 \mathrm{FNeu} 5 \mathrm{Ac} 9 \mathrm{~N}_{3}$ with the fluorine in either the equatorial or the axial position at $\mathrm{C}-3$ (Scheme 1B). In this process, a mixture of a similar ratio of $3 \mathrm{~F}\left(\right.$ a) Neu5Ac9 $\mathrm{N}_{3}$ and $3 \mathrm{~F}(e)$ Neu $5 \mathrm{Ac} 9 \mathrm{~N}_{3}$ was obtained as the end products despite either EcAldolase or PmAldolase was used as the catalyst. Nevertheless, $3 \mathrm{~F}(a) \mathrm{Neu} 5 \mathrm{Ac} 9 \mathrm{~N}_{3}$ was the major product of the EcAldolase-catalyzed reaction in the initial 5 to 8 hours while both $3 \mathrm{~F}\left(\right.$ a) Neu5 Ac9 $\mathrm{N}_{3}$ and $3 \mathrm{~F}(e) \mathrm{Neu} 5 \mathrm{Ac} 9 \mathrm{~N}_{3}$ were formed in almost the same ratio from the beginning in the PmAldolase-catalyzed reaction. In addition, the reaction catalyzed by PmAldolase was faster than the one catalyzed by EcAldolase. It was found challenging to separating $3 \mathrm{~F}\left(\right.$ a)Neu5Ac9 $\mathrm{N}_{3}$ and $3 \mathrm{~F}(e) \mathrm{Neu} 5 \mathrm{Ac} 9 \mathrm{~N}_{3}$ after the aldolase-catalyzed reaction. Therefore, they underwent protection procedures before being separated. Additional chemical modifications were carried out similarly to those described above for the synthesis of 2e3eDFNeu5Ac (1) and 2e3aDFNeu5Ac (5).

To introduce C-5 modification, sodium 3-fluoro-pyruvate and 2-azido-2-deoxymannose $\left(\mathrm{ManN}_{3}, 7 \mathbf{c}\right)^{45,46}$ were incubated in Tris- $\mathrm{HCl}$ buffer $(100 \mathrm{mM}, \mathrm{pH}=7.5)$ at $37^{\circ} \mathrm{C}$ for 4 days in the presence of PmAldolase (Scheme 1C). $3 \mathrm{~F}(e) \mathrm{Neu}_{5} \mathrm{~N}_{3}$ (11) was obtained in $68 \%$ yield after both Bio-Gel P-2 gel filtration and silica gel chromatography purification procedures. The formation of $3 \mathrm{~F}(a) \mathrm{Neu} 5 \mathrm{~N}_{3}$ was observed by thin-layer chromatography (TLC) but the yield was low and the product was not isolated. In contrast, EcAldolase did not work efficiently for this reaction. Methylation and esterification of $3 \mathrm{~F}(e) \mathrm{Neu}_{5} \mathrm{~N}_{3}(\mathbf{1 1})$ formed compound 12. Upon hydrazine acetate deprotection of the anomeric ester and treatment with DAST to introduce C-2 equatorial fluorine, compound $\mathbf{1 3}$ was obtained. Deprotection 
formed the desired $2 \mathrm{e} 3 \mathrm{eDFNeu} 5 \mathrm{~N}_{3}(3)$. It was used to synthesize $2 \mathrm{e} 3 \mathrm{eDFNeu} 5 \mathrm{Gc}(\mathbf{4})$ by hydrogenation, coupling with acetoxyacetyl chloride, followed by de-acetylation. ${ }^{32,47}$

Inhibition Studies. Direct comparison of the inhibition efficiencies of difluorosialic acids and Neu5Ac2en against different sialidases is difficult due to their different sialidase inhibition mechanisms (covalent versus noncovalent). ${ }^{34}$ Nevertheless, comparing the $\mathrm{IC}_{50}$ values obtained in a defined time frame and the time courses that covalent inhibitors loss their inhibitory activities against different sialidases can provide a clear idea about the efficiencies and the selectivity of the sialidase covalent inhibitors.

The sialidase inhibitory activities of the obtained 2,3-DFNeu5Ac and their C9- or C5modified analogs (1-6) were assessed against a recombinant human cytosolic sialidase NEU2 (hNEU2) ${ }^{40}$ and eight bacterial sialidases including commercially available sialidases from $V$. cholerae, $C$. perfringens $(\mathrm{CpNanI}$ ) and $A$. ureafaciens, as well as recombinant Streptococcus pneumoniae sialidases (SpNanA), SpNanB, and SpNanC, ${ }^{47-50}$ Bifidobacterium longum subsp. infantis ATCC15697 sialidase 2 (BiNanH2), ${ }^{51}$ and Pasteurella multocida multifunctional sialyltransferase 1 with sialidase activity (PmST1). ${ }^{44}$ Inhibition studies were carried out using Neu5Aca $2-3 \mathrm{Gal} \beta p \mathrm{NP}$ as the sialidase substrate in the presence of an excess amount of $\beta$-galactosidase. The $\beta$-galactosidase catalyzed the cleavage of Gal $\beta p \mathrm{NP}$ released by the sialidase to form para-nitrophenol ( $p \mathrm{NP})$, the majority of which was converted to para-nitrophenolate at $\mathrm{pH}$ higher than 9.5. The reading at $\mathrm{A}_{405 \mathrm{~nm}}$ correlated to the sialidase activity. ${ }^{40,52}$

Each inhibitor was initially used in a concentration of $0.1 \mathrm{mM}$ to determine its percentage inhibition values against different sialidases in a 30 min-time frame. Inhibition activities of Neu5Ac2en were also tested at the same time for comparison purpose. As shown in Table 1, neither Neu5Ac2en nor any of the difluoro-compounds is an efficient inhibitor against SpNanB, SpNanC, or PmST1. This is expected for PmST1 ${ }^{53,54}$ which has a sialidase catalytic mechanism different from others tested here. The poor inhibitory activities of difluoro-compounds (1-6), especially the non-modified $2 e 3 \mathrm{eDFNeu} 5 \mathrm{Ac}(\mathbf{1})$ and $2 e 3 a \mathrm{DFNeu} 5 \mathrm{Ac}(\mathbf{5})$, against SpNanB and SpNanC are puzzling and deserve further investigation as they have been proposed to form a glycosyl-enzyme intermediate similar as hydrolytic sialidases such as SpNanA although different products were produced. ${ }^{49,50}$ Quite interestingly, while azido substitution of 9-OH of $2 e 3 \mathrm{eDFNeu} 5 \mathrm{Ac}(\mathbf{1})$ did not affect the inhibitory activity of $2 e 3 e \mathrm{DFNeu} 5 \mathrm{Ac} 9 \mathrm{~N}_{3}(\mathbf{2})$ against hNEU2 significantly, the same modification of $2 e 3 a \mathrm{aFNeu} 5 \mathrm{Ac}(\mathbf{5})$ to $2 \mathrm{e} 3 \mathrm{aDFNeu} 5 \mathrm{Ac} 9 \mathrm{~N}_{3}$ (6) decreased its inhibitory activity against hNEU2 significantly from $69.7 \pm 0.4 \%$ to $1.5 \pm 0.3 \%$. This indicates that the stereochemistry of 3-fluorine of the difluoro-compounds affects how they interact with hNEU2 and influence its catalytic activity. For other sialidases tested including those from $A$. ureafaciens, $C$. perfringens, and $V$. cholerae as well as SpNanA and BiNanH2, the presence of $0.1 \mathrm{mM}$ of 2,3-difluoro sialic acids and analogs (compounds 1-2 and 4-6) except for $2 \mathrm{e} 3 \mathrm{eDFNeu}_{5} \mathrm{~N}_{3}(3)$ led to more than $70 \%$ inhibition with inhibitory activities comparable or better than Neu5Ac2en. For inhibitors showed less than 50\% inhibition against certain sialidases at $0.1 \mathrm{mM}$ concentration in the $30 \mathrm{~min}$-time frame under the experimental conditions used, a higher concentration $(1.0 \mathrm{mM})$ of inhibitors was used and 
the percentage inhibition data obtained were shown in Table 2. The combined data in Tables $1-2$ defined the $\mathrm{IC}_{50}$ value ranges for weak inhibitors $\left(\mathrm{IC}_{50}=0.1-1 \mathrm{mM}\right.$ or $\left.>1 \mathrm{mM}\right)$.

$\mathrm{IC}_{50}$ values of 2,3-DFNeu5Ac and their C9- or C5-modified analogs (1-6) were obtained for stronger inhibitors $\left(\mathrm{IC}_{50}<0.1 \mathrm{mM}\right)$. As shown in Table 3, in general, hydrolytic sialidases are sensitive to inhibition by DFNeu5Ac and derivatives. Intramolecular trans-sialidase (ITsialidase) SpNanB, SpNanC that catalyzes the formation of sialidase transition state analog Sia2ens, and a 2-3-sialyltransferase with sialidase activity PmST1 were not sensitive to the inhibition by difluoro-sialic acids nor Neu5Ac2en. While substitution of the 5-acetamido group in $2 e 3 \mathrm{eDFNeu} 5 \mathrm{Ac}(\mathbf{1})$ by the 5 -glycolamido group in $2 e 3 \mathrm{eDFNeu} 5 \mathrm{Gc}$ (4) was well tolerated by all hydrolytic sialidases tested including both bacterial sialidases and hNEU2, replacing the same group by an azido group in $2 e 3 e \mathrm{DFNeu}_{5} \mathrm{~N}_{3}(3)$ was not tolerated well, and the corresponding $\mathrm{IC}_{50}$ values increased for at least 10 -fold. The low inhibitory activities of $2 e 3 e \mathrm{DFNeu}_{5} \mathrm{~N}_{3}(3)$ against most sialidases tested indicate that the $\mathrm{NH}$ in the 5acetamido group of DFNeu5Ac and derivatives is important for sialidase binding.

Substitution of $\mathrm{C} 9-\mathrm{OH}$ by an azido group in general improved $\mathrm{IC}_{50}$ values against sensitive bacterial sialidases. On the contrary, the same substitution on $2 \mathrm{e} 3 \mathrm{aDFNeu} 5 \mathrm{Ac} \mathrm{N}_{3}(\mathbf{6})$ led to at least 10 -fold decrease in inhibitory activity against hNEU2 although it did not affect the hNEU2 inhibitory activity of $2 e 3 e D F N e u 5 A_{c} 9 N_{3}(2)$ significantly.

3F(a)-compounds showed 5- to 100-fold increased inhibitory activity against sensitive bacterial sialidases compared to their $3 \mathrm{~F}(e)$-counterparts. This was opposite to that observed for influenza A virus sialidases ${ }^{34}$ or hNEU2 for which $3 \mathrm{~F}(a)$-compounds were worse inhibitors compared to their $3 \mathrm{~F}(e)$-counterparts. Among all difluoro-compounds tested, $2 e 3 a \mathrm{DFNeu} 5 \mathrm{Ac} 9 \mathrm{~N}_{3}(\mathbf{6})$ was the most effective and selective inhibitor against bacterial hydrolytic sialidases including Arthrobacter ureafaciens sialidase, Clostridium perfringens sialidase (CpNanI), and SpNanA, with $\mathrm{IC}_{50}$ values of $5.2 \pm 0.1 \mathrm{nM}, 24 \pm 1 \mathrm{nM}$, and $33 \pm 2$ $\mathrm{nM}$, respectively. Its $\mathrm{IC}_{50}$ values for inhibition against $V$. cholerae sialidase and $\mathrm{BiNanH} 2$ were also at least 500-fold better than that for hNEU2. Among these, SpNanA is an essential virulence factor for $S$. pneumoniae infection and is considered a valid drug target. ${ }^{50}$

Sialidase from epidemic strains of $V$. cholerae, a causive agent of cholera is a potential drug target. ${ }^{55} \mathrm{CpNanI}$ facilitates the infection of Gram-positive pathogenic bacterium Clostridium perfringens. ${ }^{56,57}$

Time course study for sialidase de-activation and re-activation in the presence of a covalent inhibitor. As sialidase covalent inhibitors de-activate sialidases by forming a covalent sialosyl-enzyme intermediate which can be hydrolyzed in a time-dependent manner and the sialidases eventually regain activities, ${ }^{34}$ time-dependent sialidase activity loss and regain in the presence of difluorosialic acids and derivatives (1-6) were investigated. As shown in Figure 2 and Figure S2 (see ESI), among sialidases tested including pathogenic bacterial sialidases CpNanI (Figure S2A), V. cholera sialidase (Figure S2B), and SpNanA (Figure S2C), commensal bacterial sialidase BiNanH2 (Figure S2D), and human sialidase hNEU2 (Figure S2E), none of them were sensitive to difluorosialic acids and derivatives 1 and 3-5. In comparison, except for hNEU2 (Figure 2E), all bacterial sialidases tested were sensitive to $2 \mathrm{e} 3 \mathrm{aDFNeu} 5 \mathrm{Ac} 9 \mathrm{~N}_{3}(\mathbf{6})$. CpNanI (Figure 2A1), but not other bacterial sialidases tested, was also sensitive to $2 \mathrm{e} 3 \mathrm{eDFNeu} 5 \mathrm{Ac} 9 \mathrm{~N}_{3}(\mathbf{2})$ inhibition although to a less extend 
compared to its sensitivity to $2 \mathrm{e} 3 \mathrm{aDFNeu} 5 \mathrm{Ac} 9 \mathrm{~N}_{3}(\mathbf{6})$. In general, sensitive sialidases were de-activated very quickly $(<10 \mathrm{~min})$ by $2 e 3 a \mathrm{aFNeu} 5 \mathrm{Ac} 9 \mathrm{~N}_{3}(\mathbf{6})$ but the time frames for their re-activations varied significantly. The half-life for re-activation of SpNanA (Figure 2C, 25 min), BiNanH2 (Figure 2D, 4 h), V. cholerae sialidase (Figure 2B, 24 h), and CpNanI (Figure 2A2, 2 days) ranged from $25 \mathrm{~min}-2$ days. With a high inhibitory activity and a long effective time frame against pathogenic bacterial sialidases $\mathrm{CpNanI}$ and $V$. cholerae sialidase, $2 e 3 \mathrm{aDFNeu} 5 \mathrm{Ac} 9 \mathrm{~N}_{3}(\mathbf{6})$ is a promising candidate for further drug development.

\section{CONCLUSIONS}

In conclusion, six 2,3-difluorosialic acids and analogs (1-6) with a $2 \mathrm{~F}(e)$ and a $3 \mathrm{~F}(a / e)$ with or without an additional modification at C5- or $\mathrm{C} 9$ have been chemoenzymatically synthesized as potential inhibitors against bacterial sialidases. PmAldolase was shown to be a superior catalyst compared to EcAldolase for the synthesis of 3-fluorosialic acids and analogs, the precursors for the chemical synthesis of desired 2,3-difluoro-compounds. Inhibition studies showed that the $\mathrm{NH}$ in the 5-acetamido group of difluoro-sialic acids is important for the design of the sialidase inhibitors. In contrast to the observations that $2 \mathrm{e} 3 \mathrm{a}-$ difluorosialic acid analogs were worse inhibitors compared to its $3 \mathrm{~F}(e)$ counterparts against human cytosolic sialidase hNEU2 and influenza A virus sialidases, they were better inhibitors against hydrolytic bacterial sialidases tested. The azido group substitution of the C9-OH in 2,3-difluorosialic acids improved their inhibitory activity and duration against hydrolytic bacterial sialidases. $2 e 3 a \mathrm{DFNeu} 5 \mathrm{Ac} \mathrm{N}_{3}(\mathbf{6})$ has been identified as an effective and selective inhibitor with a high inhibitory activity and a long effective time-frame against pathogenic bacterial sialidases from Clostridium perfringens (CpNanI) and V. cholerae. It is a promising sialidase inhibitor that can be further developed as chemical biological tools and potential anti-bacterial therapeutics.

\section{EXPERIMENTAL SECTION}

Materials and General Methods. Chemicals were obtained from commercial suppliers and used without further purification. ${ }^{1} \mathrm{H}$ NMR, ${ }^{13} \mathrm{C}$ NMR, ${ }^{19} \mathrm{~F}$ NMR spectra were recorded on $400 \mathrm{MHz}$ Bruker Avance III and $800 \mathrm{MHz}$ Bruker Avance III spectrometers. High resolution electrospray ionization (ESI) mass spectra were obtained using Thermo Electron LTQOrbitrap XL Hybrid MS at the Mass Spectrometry Facility in the University of California, Davis. Silica gel $60 \AA$ (230-400 mesh, Sorbent Technologies) was used for flash column chromatography. Thin-layer chromatography (TLC, Sorbent Technologies) was performed on silica gel plates using anisaldehyde sugar staining or 5\% sulfuric acid in ethanol staining for detection. Gel filtration chromatography was performed with a column $(100 \mathrm{~cm} \times 2.5$ $\mathrm{cm}$ ) packed with Bio-Gel P-2 Fine resins (Bio-Rad). 3-Fluoropyruvic acid sodium salt monohydrate was from Sigma. Sialidases from $V$. cholerae, and $A$. ureafaciens were purchased from Prozyme. Sialidases from $C$. perfringens (CpNanI) was purchased from Sigma Aldrich. Recombinant Escherichia coli sialic acid aldolase ${ }^{43}$ and Pasteurella multocida sialic acid aldolase (PmAldolase), ${ }^{42} \mathrm{SpNanA}$ and SpNanB $,{ }^{48} \mathrm{SpNanC},{ }^{47}$ hNEU2, ${ }^{40}$ Bifidobacterium longum subsp. Infantis ATCC 15697 sialidase 2 (BiNanH2), ${ }^{51}$ and $\mathrm{PmST} 1{ }^{44}$ were expressed and purified as described previously. 
Chemical and Enzymatic Synthesis of 2,3-Difluorosialic Acids 1-6.

Synthesis of 5-acetamido-2,3,5-trideoxy-3-fluoro-D-erythro-a-L-gluco-non-2-

ulopyranosylonic fluoride (2e3eDFNeu5Ac) (1) and 5-acetamido-2,3,5-trideoxy-3-fluoro-Derythro-a-L-manno-non-2-ulopyranosylonic fluoride (2e3aDFNeu5Ac) (5)

Compounds $\mathbf{1}$ and $\mathbf{5}$ were chemoenzymatically synthesized similar to those reported previously 32,33 with modifications.

$\mathrm{N}$-Acetylmannosamine (ManNAc, 7a) $(1.0 \mathrm{~g}, 4.52 \mathrm{mmol})$ and 3-fluoropyruvic acid sodium salt monohydrate $(3.30 \mathrm{~g}, 22.60 \mathrm{mmol})$ were dissolved in water in a $500 \mathrm{~mL}$ Teflon container containing Tris- $\mathrm{HCl}$ buffer $(100 \mathrm{mM}, \mathrm{pH} 7.5)$ and $\mathrm{MgCl}_{2}(20 \mathrm{mM})$. After adding an appropriate amount of PmAldolase $(10 \mathrm{mg}$ ), water was added to bring the final volume of the reaction mixture to $225 \mathrm{~mL}$. The reaction was carried out by incubating the solution at $37^{\circ} \mathrm{C}$ with agitation at $100 \mathrm{rpm}$ in an incubator for 1 day. The product formation was monitored by thin layer chromatography (TLC) developed with EtOAc:MeOH: $\mathrm{H}_{2} \mathrm{O}: \mathrm{HOAc}$ $=6: 2: 1: 0.1$ (by volume) and stained with $p$-anisaldehyde sugar stain. Upon the completion of the reaction, the mixture was centrifuged. The supernatant was concentrated and passed through a Bio-Gel P-2 gel filtration column using water as an eluent. The products were further purified using a silica gel column chromatography to separate $\mathbf{8 a}(630 \mathrm{mg}, 40 \%)$ and $\mathbf{8 b}$ (940 mg, 59\%) as white solids.

\section{5-Acetamido-2,3,5-trideoxy-3-fluoro-D-erythro-a-L-gluco-non-2-ulopyranosylonic} fluoride (2e3eDFNeu5Ac, 1). Compound $8 \mathbf{a}(600 \mathrm{mg}, 1.83 \mathrm{mmol})$ was dissolved in dry $\mathrm{MeOH}(20 \mathrm{~mL})$ and ion exchange resin Amberlite ${ }^{\circledR} 120-\mathrm{H}(1.5 \mathrm{~g})$ was added. The mixture was refluxed for $5 \mathrm{~h}$ under a nitrogen atmosphere, the filtered through Celite, and washed with $\mathrm{MeOH}$. The solvent was removed in vacuo and co-evaporated with $50 \mathrm{~mL}$ of toluene for four times. The intermediate methyl ester was dried in vacuo for 12-14 h and directly used for the next step without further purification.

To a solution of intermediate in $30 \mathrm{~mL}$ pyridine at $0{ }^{\circ} \mathrm{C}, 20 \mathrm{~mL}$ acetic anhydride was added drop wisely followed by the addition of a catalytic amount of DMAP. After being stirred at $0{ }^{\circ} \mathrm{C}$ for $1 \mathrm{~h}$, the mixture was allowed to warm up to room temperature and stirred for a total of $10 \mathrm{~h}$. The solvent was removed in vacuo and co-evaporated with $30 \mathrm{~mL}$ of toluene for four times. The intermediate was used directly for the next step without further purification.

To a solution of the intermediate in dry $\mathrm{CH}_{2} \mathrm{Cl}_{2}(50 \mathrm{~mL})$, hydrazine acetate $(820 \mathrm{mg}, 9$ mmol) in dry methanol $(10 \mathrm{~mL})$ was added and the mixture was stirred at $0{ }^{\circ} \mathrm{C}$ under an inert atmosphere $\left(\mathrm{N}_{2}\right)$ for $8 \mathrm{~h}$. The mixture was evaporated and the crude product was dissolved in EtOAc $(80 \mathrm{~mL})$. The organic layer was washed sequentially with $\mathrm{HCl}(1 \mathrm{~N})$ and a saturated aqueous solution of $\mathrm{NaHCO}_{3}$, and dried using $\mathrm{Na}_{2} \mathrm{SO}_{4}$. The solvents were removed under a reduced pressure. Purification by silica gel column chromatography (EtOAc:hexane $=8: 1$, by volume) yielded compound $9 \mathbf{a}(765 \mathrm{mg}, 82 \%)$ as a white foam.

DAST ( $0.27 \mathrm{~mL}, 2.05 \mathrm{mmol})$ was added drop wisely to a solution of hemiacetal $9 \mathbf{a}$ (700 mg, $1.37 \mathrm{mmol})$ in dry $\mathrm{CH}_{2} \mathrm{Cl}_{2}(20 \mathrm{~mL})$ at $-30^{\circ} \mathrm{C}$ and the mixture was stirred under an Argon atmosphere at this temperature for 15 minutes. The reaction was quenched by adding $\mathrm{MeOH}$ 
$(400 \mu \mathrm{L})$ and the mixture was evaporated. The residue was dissolved in $\mathrm{CH}_{2} \mathrm{Cl}_{2}(30 \mathrm{~mL})$. The organic layer was washed sequentially with $\mathrm{HCl}(1 \mathrm{~N})$ and a saturated aqueous solution of $\mathrm{NaHCO}_{3}$, and dried using $\mathrm{Na}_{2} \mathrm{SO}_{4}$. The solvents were removed under a reduced pressure. Purification by silica gel column chromatography (EtOAc:hexane $=9: 1$, by volume) afforded compound 10a $(570 \mathrm{mg}, 81 \%)$ as a white foam.

To a solution of compound 10a $(550 \mathrm{mg}, 1.07 \mathrm{mmol})$ at $0{ }^{\circ} \mathrm{C}$ in $\mathrm{MeOH}(20 \mathrm{~mL}), \mathrm{NaOMe}$ $(400 \mu \mathrm{L}, 5.4 \mathrm{~N}$ in $\mathrm{MeOH}$ ) was added drop wisely. The mixture was stirred at this temperature for 2 hours, then $\mathrm{NaOH}(1 \mathrm{M}, 1.0 \mathrm{~mL})$ was added and the stirring was continued for another $2 \mathrm{~h}$. The reaction mixture was neutralized by adding ion exchange resin Amberlite ${ }^{\circledR}$ IR-120H, concentrated and purified using a C18 column on a CombiFlashRf 200 i system by eluting with a gradient of $0-100 \%$ acetonitrile in water. The fractions containing the desired product were collected, combined, and lyophilized to produce compound $\mathbf{1}$ as a white powder. The product ( $318 \mathrm{mg}, 90 \%$ ) was further purified by highperformance liquid chromatography (HPLC) using a C18 column and water and acetonitrile as solvent and lyophilized. ${ }^{1} \mathrm{H}$ NMR $\left(800 \mathrm{MHz}, \mathrm{D}_{2} \mathrm{O}\right) \delta 4.64-4.51(\mathrm{~m}, 1 \mathrm{H}), 4.38-4.31(\mathrm{~m}$, $1 \mathrm{H}), 4.24(\mathrm{~d}, J=11.2 \mathrm{~Hz}, 1 \mathrm{H}), 4.14(\mathrm{t}, J=10.4 \mathrm{~Hz}, 1 \mathrm{H}), 3.75(\mathrm{dd}, J=12.0,2.4 \mathrm{~Hz}, 1 \mathrm{H})$, $3.72-3.68(\mathrm{~m}, 1 \mathrm{H}), 3.53(\mathrm{dd}, J=12.0,6.4 \mathrm{~Hz}, 1 \mathrm{H}), 3.43(\mathrm{~d}, J=8.8 \mathrm{~Hz}, 1 \mathrm{H}), 1.98(\mathrm{~s}, 3 \mathrm{H})$; ${ }^{13} \mathrm{C}\{\mathrm{H}\}$ NMR $\left(200 \mathrm{MHz}, \mathrm{D}_{2} \mathrm{O}\right) \delta 174.3(\mathrm{~s}, 1 \mathrm{C}, \mathrm{C}=\mathrm{O}), 168.5$ (d, $\left.1 \mathrm{C}, J_{1, \mathrm{~F} 2}=32 \mathrm{~Hz}, \mathrm{C}-1\right)$, $107.0\left(\mathrm{dd}, 1 \mathrm{C}, J_{2, \mathrm{~F}}=220 \mathrm{~Hz}, J_{2, \mathrm{~F} 3}=28 \mathrm{~Hz}, \mathrm{C}-2\right), 93.2\left(\mathrm{dd}, 1 \mathrm{C}, J_{3, \mathrm{~F} 3}=186 \mathrm{~Hz}, J_{3, \mathrm{~F} 2}=30\right.$ $\mathrm{Hz}, \mathrm{C}-3$ ), 73.0 (s, 1C, C-6), 70.2 (dd, 1C, $\left.J_{4, \mathrm{~F} 3}=18 \mathrm{~Hz}, J_{4, \mathrm{~F} 2}=8 \mathrm{~Hz}, \mathrm{C}-4\right), 69.3$ (C-8), 67.2 (s, 1C, C-7), $62.6(\mathrm{~s}, 1 \mathrm{C}, \mathrm{C}-9), 49.1\left(\mathrm{~d}, 1 \mathrm{C}, J_{5, \mathrm{~F} 3}=8 \mathrm{~Hz}, \mathrm{C}-5\right), 21.4\left(\mathrm{~s}, 1 \mathrm{C}, \mathrm{NHCOCH}_{3}\right) ;{ }^{19} \mathrm{~F}$ NMR $\left(376 \mathrm{MHz}, \mathrm{D}_{2} \mathrm{O}\right) \delta-112.2(\mathrm{t}, J=13.7 \mathrm{~Hz}),-201.7$ (ddd, $\left.J=49.6,14.4,2.6 \mathrm{~Hz}\right)$; HRMS (ESI-Orbitrap) m/z: [M - H] $]^{-}$Calcd for $\mathrm{C}_{11} \mathrm{H}_{16} \mathrm{~F}_{2} \mathrm{NO}_{8} 328.0849$; found 328.0834.

\section{5-Acetamido-2,3,5-trideoxy-3-fluoro-D-erythro-a-L-manno-non-2-ulopyranosylonic} fluoride (2e3aDFNeu5Ac, 5). The synthesis of compound $\mathbf{5}(485 \mathrm{mg})$ from $\mathbf{8 b}(900 \mathrm{mg})$ was processed similarly as that described for the synthesis of compound $\mathbf{1}$ from $\mathbf{8 a} .{ }^{1} \mathrm{H}$ NMR $\left(800 \mathrm{MHz}, \mathrm{D}_{2} \mathrm{O}\right) \delta 5.01$ (dd, $1 \mathrm{H}, J=2.4$ and $\left.48.0 \mathrm{~Hz}, \mathrm{H}-3\right), 4.34$ (t, $1 \mathrm{H}, J=11.2 \mathrm{~Hz}, \mathrm{H}-5$ ), 4.14 (dd, $1 \mathrm{H}, J=12.0$ and $28.8 \mathrm{~Hz}, \mathrm{H}-4), 4.11(\mathrm{~d}, 1 \mathrm{H}, J=11.2 \mathrm{~Hz}, \mathrm{H}-6), 3.88-3.84$ (m, 2H, H-8, H-9a), 3.64 (dd, 1H, $J=6.4$ and $12.0 \mathrm{~Hz}, \mathrm{H}-9 \mathrm{~b}$ ), 3.53 (d, 1H, $J=8.8, \mathrm{H}-7$ ), 2.05 (s, 3H, $\left.\mathrm{NHCOCH}_{3}\right) ;{ }^{13} \mathrm{C}\{\mathrm{H}\}$ NMR $\left(200 \mathrm{MHz}, \mathrm{D}_{2} \mathrm{O}\right) \delta 174.7(\mathrm{~s}, \mathrm{C}=\mathrm{O}), 169.8\left(\mathrm{dd}, 1 \mathrm{C}, J_{1, \mathrm{~F} 2}=23.3\right.$ $\mathrm{Hz}, \mathrm{C}-1), 106.5$ (dd, 1C, $\left.J_{2, \mathrm{~F}}=224.7 \mathrm{~Hz}, J_{2, \mathrm{~F} 3}=29.5 \mathrm{~Hz}, \mathrm{C}-2\right), 87.5\left(\mathrm{dd}, 1 \mathrm{C}, J_{3, \mathrm{~F} 3}=176.5\right.$ $\left.\mathrm{Hz}, J_{3, \mathrm{~F} 2}=45.6 \mathrm{~Hz}, \mathrm{C}-3\right), 72.2(\mathrm{C}-6), 69.7(\mathrm{C}-8), 68.0(\mathrm{C}-7), 67.5$ (d, 1C, $\left.J=17.8 \mathrm{~Hz}\right), 63.1$ (C-9), $46.5\left(\mathrm{~d}, J_{5, \mathrm{~F} 3}=2.4 \mathrm{~Hz}, \mathrm{C}-5\right), 22.0\left(\mathrm{~s}, 1 \mathrm{C}, \mathrm{NHCOCH}_{3}\right) ;{ }^{19} \mathrm{~F} \mathrm{NMR}\left(376 \mathrm{MHz}, \mathrm{D}_{2} \mathrm{O}\right) \delta$ $-123.27\left(\mathrm{~d}, J_{\mathrm{F} 2, \mathrm{~F} 3}=13.6 \mathrm{~Hz}, \mathrm{~F}-2\right),-209.63\left(\mathrm{ddd}, J_{\mathrm{F} 3, \mathrm{H} 3}=42.9 \mathrm{~Hz}, J_{\mathrm{F} 3, \mathrm{H} 4}=29.3 \mathrm{~Hz}, J_{\mathrm{F} 3, \mathrm{~F} 2}\right.$ $=13.2 \mathrm{~Hz}, \mathrm{~F}-3$ ); HRMS (ESI-Orbitrap) $\mathrm{m} / \mathrm{z}$ : $[\mathrm{M}-\mathrm{H}]^{-}$Calcd for $\mathrm{C}_{11} \mathrm{H}_{16} \mathrm{~F}_{2} \mathrm{NO}_{8} 328.0849$; found 328.0838 .

Synthesis of 5-acetamido-9-azido-2,3,5,9-tetradeoxy-3-fluoro-D-erythro-a-L-gluconon-2-ulopyranosylonic fluoride $\left(2 e 3 e \mathrm{DFNeu}^{2} \mathrm{Ac}_{\mathrm{N}}, 2\right)$ and 5-acetamido-9azido-2,3,5,9-tetradeoxy-3-fluoro-D-erythro-a-L-manno-non-2-ulopyranosylonic fluoride (2e3aDFNeu5Ac9N 3 , 6). 6-Azido-6-deoxy- $N$-acetylmannosamine (ManNAc6N $\mathrm{N}_{3}$, $7 \mathbf{b})^{44}(1.0 \mathrm{~g}, 4.06 \mathrm{mmol})$ and 3-fluoropyruvic acid sodium salt monohydrate $(2.96 \mathrm{~g}, 20.03$ $\mathrm{mmol}$ ) were dissolved in water in a $500 \mathrm{~mL}$ Teflon container containing Tris- $\mathrm{HCl}$ buffer (100 mM, pH 7.5) and $\mathrm{MgCl}_{2}(20 \mathrm{mM})$. After the addition of an appropriate amount of 
PmAldolase (12 mg), water was added to bring the final volume of the reaction mixture to $200 \mathrm{~mL}$. The reaction was carried out by incubating the solution at $37^{\circ} \mathrm{C}$ with agitation at $100 \mathrm{rpm}$ in an incubator for 2 days. The product formation was monitored by thin layer chromatography (TLC) developed with EtOAc:MeOH:H $2 \mathrm{O}: \mathrm{HOAc}=6: 2: 1: 0.1$ (by volume) and stained with $p$-anisaldehyde sugar stain. Upon the completion of the reaction, the mixture was centrifuged. The supernatant was concentrated and passed through a Bio-Gel P-2 gel filtration using water as an eluent. The product was purified further using silica gel column chromatograph to produce a mixture of two diastereomers.

The mixture of diastereomers $(1.3 \mathrm{~g}, 3.69 \mathrm{mmol})$ was dissolved in dry $\mathrm{MeOH}(75 \mathrm{~mL})$ and ion exchange resin Amberlite ${ }^{\circledR}$ 120-H (4.5 g) was added. The mixture was refluxed for $5 \mathrm{~h}$ under a nitrogen atmosphere, filtered through Celite and washed with $\mathrm{MeOH}$. The solvent was removed in vacuo and co-evaporated with $50 \mathrm{~mL}$ of toluene for four times. The intermediate methyl ester was dried in vacuo for $12-14 \mathrm{~h}$ and used directly for the next step without further purification.

To a solution of intermediate in $75 \mathrm{~mL}$ pyridine at $0{ }^{\circ} \mathrm{C}, 50 \mathrm{~mL}$ of acetic anhydride was added drop wisely followed by the addition of a catalytic amount of DMAP. After being stirred at $0{ }^{\circ} \mathrm{C}$ for $1 \mathrm{~h}$, the mixture was allowed to warm up to room temperature and stirred for a total of $10 \mathrm{~h}$. The solvent was removed in vacuo and co-evaporated with $30 \mathrm{~mL}$ of toluene for four times. Purification by silica gel column chromatography (EtOAc:hexane = 5:1, by volume) yielded compound $\mathbf{9 c}(0.84 \mathrm{~g}, 39 \%)$ and $\mathbf{9 d}(1.01 \mathrm{~g}, 46 \%)$ as white foams.

\section{5-Acetamido-9-azido-2,3,5,9-tetradeoxy-3-fluoro-D-erythro-a-L-gluco-non-2-}

ulopyranosylonic fluoride (2e3eDFNeu5Ac9N 3,2$)$. To a solution of compound $9 \mathrm{c}(0.80 \mathrm{~g}$, $1.49 \mathrm{mmol})$ in dry $\mathrm{CH}_{2} \mathrm{Cl}_{2}(30 \mathrm{~mL})$, hydrazine acetate $(830 \mathrm{mg}, 9 \mathrm{mmol})$ in dry methanol $(10 \mathrm{~mL})$ was added and the mixture was stirred at $0{ }^{\circ} \mathrm{C}$ under an inert atmosphere $\left(\mathrm{N}_{2}\right)$ for 8 $\mathrm{h}$. The mixture was then evaporated and the crude product was dissolved in EtOAc $(80 \mathrm{~mL})$. The organic layer was washed sequentially with $\mathrm{HCl}(1 \mathrm{~N})$ and a saturated aqueous solution of $\mathrm{NaHCO}_{3}$, and dried using $\mathrm{Na}_{2} \mathrm{SO}_{4}$. The solvents were removed under a reduced pressure. The residue was dried in vacuo for 10-12 $\mathrm{h}$ and used in the next step without further purification.

DAST ( $0.30 \mathrm{~mL}, 2.23 \mathrm{mmol})$ was added drop wisely to a solution of hemiacetalin dry $\mathrm{CH}_{2} \mathrm{Cl}_{2}(25 \mathrm{~mL})$ at $-30{ }^{\circ} \mathrm{C}$ and the mixture was stirred under an argon atmosphere at this temperature for 15 minutes. The reaction was quenched by adding $\mathrm{MeOH}(250 \mu \mathrm{L})$ and the mixture was evaporated. The residue was dissolved in $\mathrm{CH}_{2} \mathrm{Cl}_{2}(30 \mathrm{~mL})$. The organic layer was washed sequentially with $\mathrm{HCl}(1 \mathrm{~N})$ and a saturated aqueous solution of $\mathrm{NaHCO}_{3}$, and dried using $\mathrm{Na}_{2} \mathrm{SO}_{4}$. The solvents were removed under a reduced pressure. Purification by silica gel column chromatography (EtOAc:hexane $=5: 1$, by volume) afforded compound $10 \mathbf{c}(577 \mathrm{mg}, 78 \%)$ as a white foam.

To a solution of compound 10c $(570 \mathrm{mg}, 1.15 \mathrm{mmol})$ in $\mathrm{MeOH}(15 \mathrm{~mL})$ at $0{ }^{\circ} \mathrm{C}, \mathrm{NaOMe}$ $(300 \mu \mathrm{L}, 5.4 \mathrm{~N}$ in $\mathrm{MeOH}$ ) was added drop wisely. The mixture was stirred at this temperature for 2 hours, then $\mathrm{NaOH}(1 \mathrm{M}, 1.0 \mathrm{~mL})$ was added and the stirring was continued for another $2 \mathrm{~h}$. The reaction mixture was neutralized by adding ion exchange resin 
Amberlite ${ }^{\circledR}$ IR- $120 \mathrm{H}$, concentrated and purified using a C18 column on a CombiFlash (Rf $200 \mathrm{i}$ system) eluted with a gradient of $0-100 \%$ acetonitrile in water. The fractions containing the desired product were collected, combined, and lyophilized to produce compound 2 as a white powder. The product ( $338 \mathrm{mg}, 83 \%$ ) was further purified by HPLC (C18 column and water and acetonitrile as solvent) and lyophilized. ${ }^{1} \mathrm{H}$ NMR $(800 \mathrm{MHz}$, $\left.\mathrm{D}_{2} \mathrm{O}\right) \delta 4.76-4.52(\mathrm{~m}, 1 \mathrm{H}), 4.49-4.37(\mathrm{~m}, 1 \mathrm{H}), 4.32(\mathrm{~d}, J=10.8 \mathrm{~Hz}, 1 \mathrm{H}), 4.20(\mathrm{t}, J=10.4$ $\mathrm{Hz}, 1 \mathrm{H}), 3.96-3.87(\mathrm{~m}, 1 \mathrm{H}), 3.59$ (dd, $J=13.2,2.8 \mathrm{~Hz}, 1 \mathrm{H}), 3.52(\mathrm{~d}, J=9.2 \mathrm{~Hz}, 1 \mathrm{H}), 3.44$ $(\mathrm{dd}, J=13.2,6.0 \mathrm{~Hz}, 1 \mathrm{H}), 2.06(\mathrm{~s}, 3 \mathrm{H}) ;{ }^{13} \mathrm{C}\{\mathrm{H}\} \mathrm{NMR}\left(200 \mathrm{MHz}, \mathrm{D}_{2} \mathrm{O}\right) \delta 174.3(\mathrm{~s}, 1 \mathrm{C}$, $\mathrm{C}=\mathrm{O}), 168.4\left(\mathrm{~d}, 1 \mathrm{C}, J_{1, \mathrm{~F} 2}=32 \mathrm{~Hz}, \mathrm{C}-1\right), 107.1\left(\mathrm{dd}, 1 \mathrm{C}, J_{2, \mathrm{~F}}=218 \mathrm{~Hz}, J_{2, \mathrm{~F} 3}=26 \mathrm{~Hz}, \mathrm{C}-2\right)$, $93.3\left(\mathrm{dd}, 1 \mathrm{C}, J_{3, \mathrm{~F} 3}=184 \mathrm{~Hz}, J_{3, \mathrm{~F} 2}=30 \mathrm{~Hz}, \mathrm{C}-3\right), 72.9(\mathrm{~s}, 1 \mathrm{C}, \mathrm{C}-6), 70.2\left(\mathrm{dd}, 1 \mathrm{C}, J_{4, \mathrm{~F} 3}=18\right.$ $\left.\mathrm{Hz}, J_{4, \mathrm{~F} 2}=6 \mathrm{~Hz}, \mathrm{C}-4\right), 68.3$ (s, 1C, C-8), 67.7 (s, 1C, C-7), 53.4 (s, 1C, C-9), 49.2 (d, 1C, $J 5, \mathrm{~F} 3=8 \mathrm{~Hz}, \mathrm{C}-5), 21.5\left(\mathrm{~s}, 1 \mathrm{C}, \mathrm{NHCOCH}_{3}\right) ;{ }^{19} \mathrm{~F} \mathrm{NMR}\left(376 \mathrm{MHz}, \mathrm{D}_{2} \mathrm{O}\right) \delta:-112.78(\mathrm{t}, J=$ $14.1 \mathrm{~Hz}$ ), -201.1 (ddd, $J=49.2,14.4,2.6 \mathrm{~Hz}$ ). HRMS (ESI-Orbitrap) m/z: [M - H] ${ }^{-}$Calcd for $\mathrm{C}_{11} \mathrm{H}_{15} \mathrm{~F}_{2} \mathrm{~N}_{4} \mathrm{O}_{7}$ 353.0914; found 353.0927.

\section{5-Acetamido-9-azido-2,3,5,9-tetradeoxy-3-fluoro-D-erythro-a-L-manno-non-2-} ulopyranosylonic fluoride $(2 e 3 a$ DFNeu5Ac9N 3 , 6). To a solution of compound $9 \mathrm{~d}(1.0 \mathrm{~g}$, $1.87 \mathrm{mmol})$ in dry $\mathrm{CH}_{2} \mathrm{Cl}_{2}(50 \mathrm{~mL})$, hydrazine acetate $(1.0 \mathrm{~g}, 11.22 \mathrm{mmol})$ in dry methanol $(15 \mathrm{~mL})$ was added and the mixture was stirred at $0{ }^{\circ} \mathrm{C}$ under an inert atmosphere $\left(\mathrm{N}_{2}\right)$ for 8 h. The mixture was then evaporated and the crude product was dissolved in EtOAc $(80 \mathrm{~mL})$. The organic layer was washed sequentially with $\mathrm{HCl}(1 \mathrm{~N})$ and a saturated aqueous solution of $\mathrm{NaHCO}_{3}$, and dried using $\mathrm{Na}_{2} \mathrm{SO}_{4}$. The solvents were removed under a reduced pressure. The residue was dried in vacuo for 10-12 $\mathrm{h}$ and used in the next step without further purification.

DAST $(0.37 \mathrm{~mL}, 2.8 \mathrm{mmol})$ was added dropwise to a solution of hemiacetal in dry $\mathrm{CH}_{2} \mathrm{Cl}_{2}$ $(30 \mathrm{~mL})$ at $-30{ }^{\circ} \mathrm{C}$ and the mixture was stirred under an Argon atmosphere at this temperature for 15 minutes. The reaction was quenched by adding $\mathrm{MeOH}(250 \mu \mathrm{L})$ and the mixture was evaporated. The residue was dissolved in $\mathrm{CH}_{2} \mathrm{Cl}_{2}(30 \mathrm{~mL})$. The organic layer was washed sequentially with $\mathrm{HCl}(1 \mathrm{~N})$ and a saturated aqueous solution of $\mathrm{NaHCO}_{3}$, and dried using $\mathrm{Na}_{2} \mathrm{SO}_{4}$. The solvents were removed under a reduced pressure. Purification by silica gel column chromatography (EtOAc:hexane $=5: 1$, by volume) afforded compound 10d $(685 \mathrm{mg}, 74 \%)$ as a white foam.

To a solution of compound 10d $(680 \mathrm{mg}, 1.38 \mathrm{mmol})$ in $\mathrm{MeOH}(25 \mathrm{~mL})$ at $0{ }^{\circ} \mathrm{C}, \mathrm{NaOMe}$ $(500 \mu \mathrm{L}, 5.4 \mathrm{~N}$ in $\mathrm{MeOH})$ was added drop wisely. The mixture was stirred at this temperature for 2 hours, then $\mathrm{NaOH}(1 \mathrm{M}, 1.5 \mathrm{~mL})$ was added and the stirring was continued for another $2 \mathrm{~h}$. The reaction mixture was neutralized by adding ion exchange resin Amberlite ${ }^{\circledR}$ IR-120H, concentrated and purified using a C18 column on a CombiFlashRf $200 \mathrm{i}$ system eluted with a gradient of $0-100 \%$ acetonitrile in water. The fractions containing the desired product were collected, combined, and lyophilized to produce compound $\mathbf{6}$ as a white powder. The product ( $400 \mathrm{mg}, 82 \%$ ) was further purified by HPLC (C18 column and water and acetonitrile as solvent) and lyophilized. ${ }^{1} \mathrm{H}$ NMR $\left(400 \mathrm{MHz}, \mathrm{D}_{2} \mathrm{O}\right) \delta 5.24-4.97$ $(\mathrm{m}, 1 \mathrm{H}), 4.20(\mathrm{t}, J=10.4 \mathrm{~Hz}, 1 \mathrm{H}), 4.15-4.00(\mathrm{~m}, 1 \mathrm{H}), 4.00-3.86(\mathrm{~m}, 1 \mathrm{H}), 3.74(\mathrm{~d}, J=10.2$ $\mathrm{Hz}, 1 \mathrm{H}), 3.57$ (dd, $J=13.2,2.8 \mathrm{~Hz}, 1 \mathrm{H}), 3.48(\mathrm{~d}, J=9.2 \mathrm{~Hz}, 1 \mathrm{H}), 3.40$ (dd, $J=13.2,6.0 \mathrm{~Hz}$, 1H), $1.97(\mathrm{~s}, 3 \mathrm{H}) ;{ }^{13} \mathrm{C}\{\mathrm{H}\}$ NMR (200 MHz, $\left.\mathrm{D}_{2} \mathrm{O}\right) \delta 174.5$ (s, 1C, C=O), 168.1 (dd, 1C, 
$J_{1, \mathrm{~F} 2}=28 \mathrm{~Hz}$ and $\left.2 \mathrm{~Hz}, \mathrm{C}-1\right), 106.3\left(\mathrm{dd}, 1 \mathrm{C}, J_{2, \mathrm{~F}}=218 \mathrm{~Hz}, J_{2, \mathrm{~F} 3}=14 \mathrm{~Hz}, \mathrm{C}-2\right), 88.5(\mathrm{dd}$, $\left.1 \mathrm{C}, J_{3, \mathrm{~F} 3}=184 \mathrm{~Hz}, J_{3, \mathrm{~F} 2}=18 \mathrm{~Hz}, \mathrm{C}-3\right), 72.1$ (s, 1C, C-6), 68.6 (s, 1C, C-8), 68.4 (dd, 1C, $\left.J_{4, \mathrm{~F} 3}=18 \mathrm{~Hz}, J_{4, \mathrm{~F} 2}=6 \mathrm{~Hz}, \mathrm{C}-4\right), 67.8(\mathrm{~s}, 1 \mathrm{C}, \mathrm{C}-7), 53.2(\mathrm{~s}, 1 \mathrm{C}, \mathrm{C}-9), 46.3(\mathrm{~d}, 1 \mathrm{C}, 55, \mathrm{~F} 3=$ $2.4 \mathrm{~Hz}, \mathrm{C}-5), 21.6\left(\mathrm{~s}, 1 \mathrm{C}, \mathrm{NHCOCH}_{3}\right) ;{ }^{19} \mathrm{~F}$ NMR $\left(376 \mathrm{MHz}, \mathrm{D}_{2} \mathrm{O}\right) \delta-121.13$ (d, $J=11.7$ $\mathrm{Hz}$ ), -217.76 (ddd, $J=51.5,28.6,11.7 \mathrm{~Hz}$ ); HRMS (ESI-Orbitrap) $\mathrm{m} / \mathrm{z}:[\mathrm{M}-\mathrm{H}]^{-}$Calcd for $\mathrm{C}_{11} \mathrm{H}_{15} \mathrm{~F}_{2} \mathrm{~N}_{4} \mathrm{O}_{7}$ 353.0914; found 353.0935 .

Synthesis of 5-azido-2,3,5-trideoxy-3-fluoro-D-erythro-a-L-gluco-non-2-ulopyranosylonic fluoride $\left(2 e 3 e \mathrm{DFNeu} 5 \mathrm{~N}_{3}\right)(3)$

5-Azido-3,5-dideoxy-3-fluoro-D-erythro-L-gluco-2-nonulopyranosonic acid (11). 2 Azidomannose $(0.5 \mathrm{~g}, 2.43 \mathrm{mmol})^{45,46}$ and 3-fluoropyruvic acid sodium salt monohydrate $(1.8 \mathrm{~g}, 12.32 \mathrm{mmol})$ were dissolved in water in a $500 \mathrm{~mL}$ Teflon container containing Tris$\mathrm{HCl}$ buffer $(100 \mathrm{mM}, \mathrm{pH} 7.5)$ and $\mathrm{MgCl}_{2}(20 \mathrm{mM})$. After the addition of an appropriate amount of PmAldolase (10 mg), water was added to bring the final volume of the reaction mixture to $100 \mathrm{~mL}$. The reaction was carried out by incubating the solution at $37{ }^{\circ} \mathrm{C}$ with agitation at $100 \mathrm{rpm}$ in an incubator for 4 days. The product formation was monitored by thin layer chromatography (TLC) developed with EtOAc:MeOH: $\mathrm{H}_{2} \mathrm{O}: \mathrm{HOAc}=6: 2: 1: 0.1$ (by volume) and stained with $p$-anisaldehyde sugar stain. Upon the completion of the reaction, the mixture was centrifuged. The supernatant was concentrated and passed through a BioGel P-2 gel filtration using water as an eluent. The product was purified further using silica gel chromatograph to produce $11(516 \mathrm{mg}, 68 \%) .{ }^{1} \mathrm{H} \mathrm{NMR}\left(800 \mathrm{MHz}, \mathrm{D}_{2} \mathrm{O}\right) \delta 4.60(\mathrm{dd}, J=$ 49.6, $8.8 \mathrm{~Hz}, 1 \mathrm{H}), 4.08(\mathrm{dd}, J=22.4,9.6 \mathrm{~Hz}, 1 \mathrm{H}), 3.94(\mathrm{~d}, J=10.4 \mathrm{~Hz}, 1 \mathrm{H}), 3.84(\mathrm{~d}, J=$ $12.0 \mathrm{~Hz}, 1 \mathrm{H}), 3.77-3.70(\mathrm{~m}, 2 \mathrm{H}), 3.68(\mathrm{t}, J=9.6 \mathrm{~Hz}, 1 \mathrm{H}), 3.63(\mathrm{dd}, J=12.0,6.4 \mathrm{~Hz}, 1 \mathrm{H})$; ${ }^{13} \mathrm{C}\{\mathrm{H}\} \mathrm{NMR}\left(200 \mathrm{MHz}, \mathrm{D}_{2} \mathrm{O}\right) \delta 173.1$ (s, $\left.1 \mathrm{C}, \mathrm{C}-1\right), 94.2\left(\mathrm{~d}, 1 \mathrm{C}, J_{2, \mathrm{~F} 3}=20 \mathrm{~Hz}, \mathrm{C}-2\right), 91.1$ $\left(\mathrm{d}, 1 \mathrm{C}, J_{3, \mathrm{~F} 3}=188 \mathrm{~Hz}, \mathrm{C}-3\right), 70.7\left(\mathrm{~d}, 1 \mathrm{C}, J_{4, \mathrm{~F} 3}=18 \mathrm{~Hz}, \mathrm{C}-4\right), 69.6$ (s, 1C, C-6), $69.2(\mathrm{~s}, 1 \mathrm{C}$, C-8), 68.0 (s, 1C, C-7), 62.7 (s, 1C, C-9), 61.0 (d, 1C, J5,F3 = 8 Hz, C-5); ${ }^{19}$ F NMR (376 $\mathrm{MHz}, \mathrm{D}_{2} \mathrm{O}$ ) $\delta-200.2\left(\mathrm{dd}, J=52.8,13.6 \mathrm{~Hz}\right.$ ); HRMS (ESI-Orbitrap) $\mathrm{m} / \mathrm{z}$ : [M - H] ${ }^{-}$Calcd for $\mathrm{C}_{9} \mathrm{H}_{13} \mathrm{FN}_{3} \mathrm{O}_{8} 310.0692$; found 310.0675 .

Methyl 5-azido-2,4,7,8,9-penta-O-acetyl-3,5-dideoxy-3-fluoro-D-erythro-L-gluco-non-2ulopyranosonate (12). Compound $11(0.5 \mathrm{~g}, 1.6 \mathrm{mmol})$ was dissolved in dry $\mathrm{MeOH}$ (50 $\mathrm{mL}$ ) and ion exchange resin Amberlite ${ }^{\circledR} 120-\mathrm{H}(1.5 \mathrm{~g})$ was added. The mixture was refluxed for $5 \mathrm{~h}$ under a nitrogen atmosphere, filtered through Celite and washed with $\mathrm{MeOH}$. The solvent was removed in vacuo and co-evaporated with $20 \mathrm{~mL}$ of toluene for four times. The intermediate methyl ester was dried in vacuo for 12-14 $\mathrm{h}$ and directly used for the next step without further purification.

To a solution of intermediate in $30 \mathrm{~mL}$ pyridine at $0{ }^{\circ} \mathrm{C}, 25 \mathrm{~mL}$ of acetic anhydride was added drop wisely followed by the addition of a catalytic amount of DMAP. After being stirred at $0{ }^{\circ} \mathrm{C}$ for $1 \mathrm{~h}$, the mixture was allowed to warm up to room temperature and stirred for a total of $10 \mathrm{~h}$. The solvent was removed in vacuo and co-evaporated with $30 \mathrm{~mL}$ of toluene for four times. Purification by silica gel column chromatography (EtOAc:hexane $=$ 1:1, by volume) yielded compound $12(697 \mathrm{mg}, 81 \%)$ as a white foam. ${ }^{1} \mathrm{H}$ NMR $(800 \mathrm{MHz}$, $\left.\mathrm{CDCl}_{3}\right) \delta 5.56(\mathrm{dt}, J=11.2,9.6 \mathrm{~Hz}, 1 \mathrm{H}), 5.47(\mathrm{dd}, J=7.2,1.6 \mathrm{~Hz}, 1 \mathrm{H}), 5.13(\mathrm{~m}, 1 \mathrm{H}), 4.49$ $(\mathrm{dd}, J=48.8,9.6 \mathrm{~Hz}, 1 \mathrm{H}), 4.41(\mathrm{dd}, J=12.8,2.4 \mathrm{~Hz}, 1 \mathrm{H}), 4.20(\mathrm{dd}, J=12.8,4.8 \mathrm{~Hz}, 1 \mathrm{H})$, 
$3.82(\mathrm{~s}, 3 \mathrm{H}), 3.71(\mathrm{dd}, J=11.2,1.6 \mathrm{~Hz}, 1 \mathrm{H}), 3.42(\mathrm{t}, J=10.4 \mathrm{~Hz}, 1 \mathrm{H}), 2.21(\mathrm{~s}, 41 \mathrm{H}), 2.19$ (s, $3 \mathrm{H}), 2.18(\mathrm{~s}, 3 \mathrm{H}), 2.04(\mathrm{~s}, 6 \mathrm{H}) ;{ }^{13} \mathrm{C}\{\mathrm{H}\} \mathrm{NMR}\left(200 \mathrm{MHz}, \mathrm{CDCl}_{3}\right) \delta 170.7$ (s, 1C, C=O), 170.0 (s, 1C, C=O), 169.6 (s, 1C, C=O), 169.4 (s, 1C, C=O), 167.7 (s, 1C, C=O), 164.3 (s, $1 \mathrm{C}, \mathrm{C}-1), 95.1\left(\mathrm{~d}, 1 \mathrm{C}, J_{2, \mathrm{~F} 3}=20 \mathrm{~Hz}, \mathrm{C}-2\right), 87.9\left(\mathrm{~d}, 1 \mathrm{C}, J_{3, \mathrm{~F} 3}=204 \mathrm{~Hz}, \mathrm{C}-3\right), 71.2(\mathrm{~d}, 1 \mathrm{C}$, $\left.J_{4, \mathrm{~F} 3}=20 \mathrm{~Hz}, \mathrm{C}-4\right), 70.7$ (s, 1C, C-6), 69.8 (s, 1C, C-8), 67.8 (s, 1C, C-7), 61.4 (s, 1C, C-9), $59.5(\mathrm{~d}, 1 \mathrm{C}, 55, \mathrm{~F} 3=6 \mathrm{~Hz}, \mathrm{C}-5), 53.6(\mathrm{~s}, 1 \mathrm{C}, \mathrm{COOMe}), 20.9$ (s, 1C, $\left.\mathrm{COCH}_{3}\right), 20.8(\mathrm{~s}, 2 \mathrm{C}$, $\left.\mathrm{COCH}_{3}\right), 20.7\left(\mathrm{~s}, 2 \mathrm{C}, \mathrm{COCH}_{3}\right) ;{ }^{19} \mathrm{~F} \mathrm{NMR}\left(376 \mathrm{MHz}, \mathrm{D}_{2} \mathrm{O}\right) \delta-201.1(\mathrm{dd}, J=52.0,12.0$ $\mathrm{Hz}$ ); HRMS (ESI-Orbitrap) m/z: [M + Na] ${ }^{+}$Calcd for $\mathrm{C}_{20} \mathrm{H}_{26} \mathrm{FN}_{3} \mathrm{O}_{13} \mathrm{Na}$ 558.1342; found 558.1368.

Methyl 5-acetamido-4,7,8,9-tetra- $O$-acetyl-2,3,5-trideoxy-3-fluoro-D-erythro-a-L-gluconon-2-ulopyranosylonate fluoride (13). To a solution of compound $\mathbf{1 2}(650 \mathrm{mg}, 1.21$ mmol) in dry $\mathrm{CH}_{2} \mathrm{Cl}_{2}(15 \mathrm{~mL})$, hydrazine acetate $(552 \mathrm{mg}, 6 \mathrm{mmol})$ in dry methanol $(4 \mathrm{~mL})$ was added and the mixture was stirred at $0{ }^{\circ} \mathrm{C}$ under an inert atmosphere $\left(\mathrm{N}_{2}\right)$ for $8 \mathrm{~h}$. The mixture was then evaporated and the crude product was dissolved in EtOAc $(50 \mathrm{~mL})$. The organic layer was washed sequentially with $\mathrm{HCl}(1 \mathrm{~N})$ and a saturated aqueous solution of $\mathrm{NaHCO}_{3}$, and dried using $\mathrm{Na}_{2} \mathrm{SO}_{4}$. The solvents were removed under a reduced pressure. The residue was dried in vacuo for 10-12 $\mathrm{h}$ and used in the next step without further purification.

DAST $(0.24 \mathrm{~mL}, 1.81 \mathrm{mmol})$ was added drop wisely to a solution of hemiacetal in dry $\mathrm{CH}_{2} \mathrm{Cl}_{2}(15 \mathrm{~mL})$ at $-30{ }^{\circ} \mathrm{C}$ and the mixture was stirred under an Argon atmosphere at this temperature for 15 minutes. The reaction was quenched by addition of $\mathrm{MeOH}(100 \mu \mathrm{L})$ and the mixture was evaporated. The residue was dissolved in $\mathrm{CH}_{2} \mathrm{Cl}_{2}(30 \mathrm{~mL})$. The organic layer was washed sequentially with $\mathrm{HCl}(1 \mathrm{~N})$ and a saturated aqueous solution of $\mathrm{NaHCO}_{3}$, and dried using $\mathrm{Na}_{2} \mathrm{SO}_{4}$. The solvents were removed under a reduced pressure. Purification by silica gel column chromatography (EtOAc:hexane $=1: 1$, by volume) produced compound 13 (469 mg, 78\%) as a white foam. ${ }^{1} \mathrm{H}$ NMR $\left(800 \mathrm{MHz}, \mathrm{CDCl}_{3}\right) \delta 5.67$ (ddd, $J=15.2,9.6$, $8.0 \mathrm{~Hz}, 1 \mathrm{H}), 5.45(\mathrm{~d}, J=8.8 \mathrm{~Hz}, 1 \mathrm{H}), 5.34(\mathrm{~m}, 1 \mathrm{H}), 4.59(\mathrm{~m}, 1 \mathrm{H}), 4.28(\mathrm{dd}, J=12.0,2.4 \mathrm{~Hz}$, $1 \mathrm{H}), 4.20(\mathrm{dd}, J=12.0,4.8 \mathrm{~Hz}, 1 \mathrm{H}), 4.16(\mathrm{~d}, J=10.4 \mathrm{~Hz}, 1 \mathrm{H}), 3.88(\mathrm{~s}, 3 \mathrm{H}), 3.46(\mathrm{t}, J=10.4$ $\mathrm{Hz}, 1 \mathrm{H}), 2.18(\mathrm{~s}, 3 \mathrm{H}), 2.18(\mathrm{~s}, 3 \mathrm{H}), 2.08(\mathrm{~s}, 3 \mathrm{H}), 2.06(\mathrm{~s}, 3 \mathrm{H}) ;{ }^{13} \mathrm{C}\{\mathrm{H}\} \mathrm{NMR}(200 \mathrm{MHz}$, $\mathrm{CDCl}_{3}$ ) $\delta 170.7$ (s, 1C, C=O), 169.9 (s, 1C, C=O), 169.5 (s, 1C, C=O), 169.2 (s, 1C, C=O), $164.4\left(\mathrm{~d}, 1 \mathrm{C}, J_{1, \mathrm{~F} 2}=32 \mathrm{~Hz}, \mathrm{C}-1\right), 106.1\left(\mathrm{dd}, 1 \mathrm{C}, J_{2, \mathrm{~F}}=230 \mathrm{~Hz}, J_{2, \mathrm{~F} 3}=28 \mathrm{~Hz}, \mathrm{C}-2\right), 90.6$ $\left(\mathrm{dd}, 1 \mathrm{C}, J_{3, \mathrm{~F} 3}=192 \mathrm{~Hz}, J_{3, \mathrm{~F} 2}=30 \mathrm{~Hz}, \mathrm{C}-3\right), 72.4(\mathrm{~s}, 1 \mathrm{C}, \mathrm{C}-6), 72.1\left(\mathrm{dd}, 1 \mathrm{C}, J_{4, \mathrm{~F} 3}=22 \mathrm{~Hz}\right.$, $\left.J_{4, \mathrm{~F} 2}=6 \mathrm{~Hz}, \mathrm{C}-4\right), 68.1(\mathrm{~s}, 1 \mathrm{C}, \mathrm{C}-8), 67.1(\mathrm{~s}, 1 \mathrm{C}, \mathrm{C}-7), 61.8(\mathrm{~s}, 1 \mathrm{C}, \mathrm{C}-7), 58.5(\mathrm{~d}, 1 \mathrm{C}, J 5, \mathrm{~F} 3$ $=6 \mathrm{~Hz}, \mathrm{C}-5), 53.7(\mathrm{~s}, 1 \mathrm{C}, \mathrm{COOMe}), 20.8\left(\mathrm{~s}, 1 \mathrm{C}, \mathrm{COCH}_{3}\right), 20.7\left(\mathrm{~s}, 2 \mathrm{C}, \mathrm{COCH}_{3}\right), 20.6(\mathrm{~s}, 1 \mathrm{C}$, $\left.\mathrm{COCH}_{3}\right) ;{ }^{19} \mathrm{~F} \mathrm{NMR}\left(376 \mathrm{MHz}, \mathrm{CDCl}_{3}\right) \delta-116.94$ (t, $J=14.0 \mathrm{~Hz}$ ), -200.37 (dt, $J=48.5$, 14.6 Hz); HRMS (ESI-Orbitrap) m/z: [M+Na] ${ }^{+}$Calcd for $\mathrm{C}_{18} \mathrm{H}_{23} \mathrm{~F}_{2} \mathrm{~N}_{3} \mathrm{O}_{11} \mathrm{Na} 518.1193$; found 518.1209.

\section{5-Azido-2,3,5-trideoxy-3-fluoro-D-erythro-a-L-gluco-non-2-ulopyranosylonic fluoride}

$(2 e 3 e$ DFNeu5N 3 , 3). To a solution of compound $13(450 \mathrm{mg}, 0.90 \mathrm{mmol})$ in $\mathrm{MeOH}(10 \mathrm{~mL})$ at $0{ }^{\circ} \mathrm{C}, \mathrm{NaOMe}(300 \mu \mathrm{L}, 5.4 \mathrm{~N}$ in $\mathrm{MeOH})$ was added drop wisely. The mixture was stirred at this temperature for 2 hours, then $\mathrm{NaOH}(1 \mathrm{M}, 1.5 \mathrm{~mL})$ was added and the stirring was continued for another $2 \mathrm{~h}$. The reaction mixture was neutralized by adding ion exchange resin Amberlite ${ }^{\circledR} \mathrm{IR}-120 \mathrm{H}$, concentrated and purified using a C18 column on a CombiFlash 
(Rf 200i system) eluted with a gradient of $0-100 \%$ acetonitrile in water. The fractions containing the desired product were collected, combined, and lyophilized to produce compound $\mathbf{3}$ as a white powder. The product ( $270 \mathrm{mg}$, 95\%) was further purified by HPLC (C18 column and water and acetonitrile as solvent) and lyophilized. ${ }^{1} \mathrm{H}$ NMR $(800 \mathrm{MHz}$, $\left.\mathrm{D}_{2} \mathrm{O}\right) \delta 4.66-4.57(\mathrm{~m}, 1 \mathrm{H}), 4.45(\mathrm{dt}, J=16.8,8.8 \mathrm{~Hz}, 1 \mathrm{H}), 4.20(\mathrm{~d}, J=10.4 \mathrm{~Hz}, 1 \mathrm{H}), 3.83$ $(\mathrm{d}, J=12.0 \mathrm{~Hz}, 1 \mathrm{H}), 3.79-3.72(\mathrm{~m}, 3 \mathrm{H}), 3.62(\mathrm{dd}, J=11.2,5.6 \mathrm{~Hz}, 1 \mathrm{H}) ;{ }^{13} \mathrm{C}\{\mathrm{H}\}$ NMR $(200$ $\left.\mathrm{MHz}, \mathrm{D}_{2} \mathrm{O}\right) \delta 168.5\left(\mathrm{~d}, 1 \mathrm{C}, J_{1, \mathrm{~F} 2}=32 \mathrm{~Hz}, \mathrm{C}-1\right), 107.2\left(\mathrm{dd}, 1 \mathrm{C}, J_{2, \mathrm{~F}}=222 \mathrm{~Hz}, J_{2, \mathrm{~F} 3}=28 \mathrm{~Hz}\right.$, $\mathrm{C}-2), 92.9\left(\mathrm{dd}, 1 \mathrm{C}, J_{3, \mathrm{~F} 3}=186 \mathrm{~Hz}, J_{3, \mathrm{~F} 2}=30 \mathrm{~Hz}, \mathrm{C}-3\right), 73.0(\mathrm{~s}, 1 \mathrm{C}, \mathrm{C}-6), 71.5\left(\mathrm{dd}, 1 \mathrm{C}, J_{4, \mathrm{~F} 3}=\right.$ $\left.20 \mathrm{~Hz}, J_{4, \mathrm{~F} 2}=6 \mathrm{~Hz}, \mathrm{C}-4\right), 69.4$ (s, 1C, C-8), 67.6 (s, 1C, C-7), 62.7 (s, 1C, C-9), 59.6 (d, 1C, $J 5, \mathrm{~F} 3=8 \mathrm{~Hz}, \mathrm{C}-5) ;{ }^{19} \mathrm{~F}$ NMR $\left(376 \mathrm{MHz}, \mathrm{D}_{2} \mathrm{O}\right) \delta-112.26(\mathrm{t}, J=13.5 \mathrm{~Hz}),-200.37$ (ddd, $J$ $=49.2,14.7,3.0 \mathrm{~Hz}$ ); HRMS (ESI-Orbitrap) $\mathrm{m} / \mathrm{z}:[\mathrm{M}-\mathrm{H}]^{-}$Calcd for $\mathrm{C}_{9} \mathrm{H}_{12} \mathrm{~F}_{2} \mathrm{~N}_{3} \mathrm{O}_{7}$ 312.0649 ; found 312.0635 .

Synthesis of 5-glycolamido-2,3,5-trideoxy-3-fluoro-D-erythro-a-L-gluco-non-2ulopyranosylonic fluoride $(2 e 3 e$ DFNeu5Gc, 4). To a solution of compound $3(150 \mathrm{mg}$, $0.48 \mathrm{mmol})$ in $\mathrm{CH}_{3} \mathrm{OH}$ : Water $(5 \mathrm{~mL}, 1: 1 \mathrm{v} / \mathrm{v}), 20 \% \mathrm{Pd}(\mathrm{OH})_{2} / \mathrm{C}(40 \mathrm{mg})$ was added and the reaction mixture was stirred at room temperature under a positive pressure of hydrogen for 5 h. The reaction mixture was filtered through a Celite ${ }^{\circledR}$ bed and evaporated to dryness. The intermediate amine was dried in vacuo for 12-14 $\mathrm{h}$ and directly used for the next step without further purification.

The amine intermediate $(134.5 \mathrm{mg}, 0.47 \mathrm{mmol})$ was dissolved in $\mathrm{CH}_{3} \mathrm{CN}-\mathrm{H}_{2} \mathrm{O}(4 \mathrm{~mL}, 1: 1$, $\mathrm{v} / \mathrm{v})$. Then solid $\mathrm{NaHCO}_{3}(390 \mathrm{mg}, 4.7 \mathrm{mmol})$ and acetoxyacetyl chloride $(252 \mu \mathrm{L}, 2.35$ $\mathrm{mmol})$ in $\mathrm{CH}_{3} \mathrm{CN}(1 \mathrm{~mL})$ were added. The reaction mixture was stirred for 3 hours at $0{ }^{\circ} \mathrm{C}$ and neutralized by adding acetic acid, concentrated, and purified by Bio-Gel-P2. Compoundcontaining fractions were combined and dried. The dried compound was dissolved in $\mathrm{MeOH}$ $(4 \mathrm{~mL})$ and $\mathrm{NaOMe}(200 \mu \mathrm{L}, 5.4 \mathrm{~N}$ in $\mathrm{MeOH})$ was added drop wisely at $0{ }^{\circ} \mathrm{C}$. The mixture was stirred at room temperature for 2 hours. The reaction mixture was neutralized by adding ion exchange resin Amberlite $\AA$ IR-120H, concentrated and purified using a C18 column on a CombiFlashRf 200i system eluted with a gradient of 0-100\% acetonitrile in water. The fractions containing the desired product were collected, combined, and lyophilized to produce compound 4 as a white powder. The product (142.2 $\mathrm{mg}, 88 \%$ ) was further purified by HPLC (C18 column and water and acetonitrile as solvent) and lyophilized. ${ }^{1} \mathrm{H}$ NMR (800 $\left.\mathrm{MHz}, \mathrm{D}_{2} \mathrm{O}\right) \delta 4.70-4.58(\mathrm{~m}, 1 \mathrm{H}), 4.48(\mathrm{dt}, J=17.6,9.6 \mathrm{~Hz}, 1 \mathrm{H}), 4.39(\mathrm{~d}, J=11.2 \mathrm{~Hz}, 1 \mathrm{H})$, $4.27(\mathrm{t}, J=10.4 \mathrm{~Hz}, 1 \mathrm{H}), 4.12(\mathrm{~s}, 2 \mathrm{H}), 3.79(\mathrm{dd}, J=12.0,2.4 \mathrm{~Hz}, 1 \mathrm{H}), 3.76-3.70(\mathrm{~m}, 1 \mathrm{H})$, $3.58(\mathrm{dd}, J=12.0,6.4 \mathrm{~Hz}, 1 \mathrm{H}), 3.48(\mathrm{~d}, J=8.8 \mathrm{~Hz}, 1 \mathrm{H}) ;{ }^{13} \mathrm{C}\{\mathrm{H}\} \mathrm{NMR}\left(200 \mathrm{MHz}, \mathrm{D}_{2} \mathrm{O}\right) \delta$ $175.2(\mathrm{~s}, 1 \mathrm{C}, \mathrm{C}=\mathrm{O}), 168.4\left(\mathrm{~d}, 1 \mathrm{C}, J_{1, \mathrm{~F} 2}=32 \mathrm{~Hz}, \mathrm{C}-1\right), 107.1\left(\mathrm{dd}, 1 \mathrm{C}, J_{2, \mathrm{~F}}=220 \mathrm{~Hz}, J_{2, \mathrm{~F} 3}=\right.$ $28 \mathrm{~Hz}, \mathrm{C}-2), 93.2\left(\mathrm{dd}, 1 \mathrm{C}, J_{3, \mathrm{~F} 3}=184 \mathrm{~Hz}, J_{3, \mathrm{~F} 2}=30 \mathrm{~Hz}, \mathrm{C}-3\right), 69.4(\mathrm{~s}, 1 \mathrm{C}, \mathrm{C}-8), 72.9$ (s,1C, $\mathrm{C}-6), 70.0\left(\mathrm{dd}, 1 \mathrm{C}, J_{4, \mathrm{~F} 3}=20 \mathrm{~Hz}, J_{4, \mathrm{~F} 2}=8 \mathrm{~Hz}, \mathrm{C}-4\right), 67.2(\mathrm{~s}, 1 \mathrm{C}, \mathrm{C}-7), 62.6$ (s, 1C, C-9), $60.5\left(\mathrm{~s}, 1 \mathrm{C}, \mathrm{NHCH}_{2} \mathrm{OH}\right), 48.8(\mathrm{~d}, 1 \mathrm{C}, 55, \mathrm{~F} 3=8 \mathrm{~Hz}, \mathrm{C}-5) ;{ }^{19} \mathrm{~F} \mathrm{NMR}\left(376 \mathrm{MHz}, \mathrm{D}_{2} \mathrm{O}\right) \delta$ : $-112.8(\mathrm{t}, J=13.7 \mathrm{~Hz}$ ), -200.9 (ddd, $J=49.6,14.8,2.6 \mathrm{~Hz}$ ); HRMS (ESI-Orbitrap) m/z: [M $-\mathrm{H}]^{-}$Calcd for $\mathrm{C}_{11} \mathrm{H}_{16} \mathrm{~F}_{2} \mathrm{NO}_{9} 344.0799$; found 344.0792 .

Inhibition Assay. Percentage Inhibition assays were carried out in duplicates in a 384-well plate similar to that reported previously. ${ }^{24}$ All reactions had a final volume of $20 \mu \mathrm{L}$ containing Neu5Aca2-3Gal $\beta p \mathrm{NP}(0.3 \mathrm{mM})$ and $\beta$-galactosidase $(12 \mu \mathrm{g})$ with $0.1 \mathrm{mM}$ or 1.0 
$\mathrm{mM}$ of inhibitor. The assay conditions for various sialidases were as follows: $A$. ureafaciens sialidase (0.5 mU), NaOAc buffer (100 mM, pH 5.5); $C$. perfringens sialidase (CpNanI, 1.3 $\mathrm{mU})$, MES buffer (100 mM, pH 5.0); $V$. cholera sialidase (0.6 mU), $\mathrm{NaCl}(150 \mathrm{mM}), \mathrm{CaCl}_{2}$ (10 mM), NaOAc buffer (100 mM, pH 5.5); SpNanA (0.75 ng), NaOAc buffer (100 mM, pH 6.0); SpNanB (3 ng), NaOAc buffer (100 mM, pH 6.0); SpNanC (10 ng), MES buffer (100 mM, pH 6.5); PmST1 (0.2 $\mu \mathrm{g})$, NaOAc buffer (100 mM, pH 5.5), CMP (0.4 mM); hNEU2 $(0.6 \mu \mathrm{g})$, MES buffer (100 mM, pH 5.0); BiNanH2 (4 ng), NaOAc buffer (100 mM, pH 5.0). The reactions were carried out for 30 minutes and quenched with $40 \mu \mathrm{L}$ of $N$-cyclohexyl-3aminopropane sulfonic acid (CAPS) buffer (0.5 M, pH 10.5). The concentrations of $p$ nitrophenolate formed was determined by measuring $\mathrm{A}_{405 \mathrm{~nm}}$ of the reaction mixtures using a microplate reader.

Inhibition assays for obtaining $\mathrm{IC}_{50}$ values were carried out in duplicates in a 384-well plate similarly as described above except that twelve different concentrations of inhibitors in the range of 0 to $10 \mathrm{mM}$ were used (varied from $10 \mathrm{mM}, 5 \mathrm{mM}, 2.5 \mathrm{mM}, 1 \mathrm{mM}, 0.5 \mathrm{mM}, 0.1$ $\mathrm{mM}, 50 \mu \mathrm{M}, 25 \mu \mathrm{M}, 10 \mu \mathrm{M}, 5 \mu \mathrm{M}, 2.5 \mu \mathrm{M}, 1 \mu \mathrm{M}, 0.5 \mu \mathrm{M}, 0.1 \mu \mathrm{M}, 50 \mathrm{nM}, 10 \mathrm{nM}, 5 \mathrm{nM}$, and $0 \mathrm{nM}) . \mathrm{IC}_{50}$ values were obtained by fitting the average values to get the concentrationresponse plots using software Grafit 5.0.

Time course study for sialidase re-activation in the presence of a covalent inhibitor. This study was carried out in duplicates in a 384-well plate by incubating an inhibitor selected from difluorosialic acids and derivatives (1-6) and a sialidase in a 2:1 molar ratio in the presence of $\mathrm{NaOAc}$ buffer $(100 \mathrm{mM}, \mathrm{pH}$ 6.0) with (for $V$. cholera sialidase) or without (for all other sialidases) $\mathrm{CaCl}_{2}(10 \mathrm{mM})$ and $\mathrm{NaCl}(150 \mathrm{mM})$ at room temperature $\left(23^{\circ} \mathrm{C}\right)$. At different time intervals ( $2 \mathrm{~min}-24$ hours or for up to 5 days), an aliquot $(12 \mu \mathrm{L})$ of each pre-incubated inhibitor-sialidase mixture was assayed for sialidase activity using Neu5Aca2-3Gal $\beta p N P(2 \mathrm{mM})$ as the substrate in the presence of an excess amount of $\beta$ galactosidase $(12 \mu \mathrm{g})$. BioTek Synergy HT plate reader was used for continuous reading of the formation of para-nitrophenol $(p \mathrm{NP})$. The absorbance change rates $\left(\mathrm{A}_{400 \mathrm{~nm}} \mathrm{~min}^{-1}\right)$ were recorded and used for plotting Figure 2. The amounts of enzymes used were: $C$. perfringens sialidase (CpNanI, $2.0 \mu \mathrm{g})$, V. cholera sialidase $(0.25 \mu \mathrm{g})$, BiNanH2 $(0.10 \mu \mathrm{g})$, SpNanA (18 ng), hNEU2 $(1.75 \mu \mathrm{g})$.

\section{Supplementary Material}

Refer to Web version on PubMed Central for supplementary material.

\section{ACKNOWLEDGMENTS}

This work was partially supported by United States National Institutes of Health grants R01AI130684 and R43AI108115. Bruker Avance-800 NMR spectrometer was funded by United States National Science Foundation grant DBIO-722538.

\section{REFERENCES}

(1). Varki A Sialic Acids in Human Health and Disease. Trends. Mol. Med 2008, 14, 351-360. [PubMed: 18606570] 
(2). Chen X; Varki A Advances in the Biology and Chemistry of Sialic Acids. ACS Chem. Biol 2010, 5, 163-176. [PubMed: 20020717]

(3). Li Y; Chen X Sialic Acid Metabolism and Sialyltransferases: Natural Functions and Applications. Appl. Microbiol. Biotechnol 2012, 94, 887-905. [PubMed: 22526796]

(4). Taylor G Sialidases: Structures, Biological Significance and Therapeutic Potential. Curr. Opin. Struct. Biol 1996, 6, 830-837. [PubMed: 8994884]

(5). Vimr ER; Kalivoda KA; Deszo EL; Steenbergen SM Diversity of Microbial Sialic Acid Metabolism. Microbiol. Mol. Biol. Rev 2004, 68, 132-153. [PubMed: 15007099]

(6). Gallego MP; Hulen C Influence of Sialic Acid and Bacterial Sialidase on Differential Adhesion of Pseudomonas aeruginosa to Epithelial Cells. Colloids Surf. B. Biointerfaces 2006, 52, 154-156. [PubMed: 16781124]

(7). Honma K; Mishima E; Sharma A Role of Tannerella forsythia NanH Sialidase in Epithelial Cell Attachment. Infect. Immun 2011, 79, 393-401. [PubMed: 21078857]

(8). King S Pneumococcal Modification of Host Sugars: a Major Contributor to Colonization of the Human Airway? Mol. Oral. Microbiol 2010, 25, 15-24. [PubMed: 20331791]

9). Li J; Sayeed S; Robertson S; Chen J; McClane BA Sialidases Affect the Host Cell Adherence and Epsilon Toxin-Induced Cytotoxicity of Clostridium perfringens type D Strain CN3718. PLoS Pathog. 2011, 7, e1002429. [PubMed: 22174687]

(10). Gualdi L; Hayre JK; Gerlini A; Bidossi A; Colomba L; Trappetti C; Pozzi G; Docquier JD; Andrew P; Ricci S; Oggioni MR Regulation of Neuraminidase Expression in Streptococcus pneumoniae. BMC Microbiol. 2012, 12, 200. [PubMed: 22963456]

(11). Roy S; Douglas CW; Stafford GP A Novel Sialic Acid Utilization and Uptake System in the Periodontal Pathogen Tannerella forsythia. J. Bacteriol 2010, 192, 2285-93.. [PubMed: 20190043]

(12). Corfield T Bacterial Sialidases-Roles in Pathogenicity and Nutrition. Glycobiology 1992, 2, 509-521. [PubMed: 1472757]

(13). Brear P; Telford J; Taylor GL; Westwood NJ Synthesis and Structural Characterisation of Selective Non-Carbohydrate-Based Inhibitors of Bacterial Sialidases. ChemBioChem 2012, 13, 2374-2383. [PubMed: 23070966]

(14). Li J; McClane BA The sialidases of Clostridium perfringens Type D Strain CN3718 Differ in Their Properties and Sensitivities to Inhibitors. Appl. Environ. Microbiol 2014, 80, 1701-1709. [PubMed: 24375134]

(15). von Itzstein M; Wu WY; Kok GB; Pegg MS; Dyason JC; Jin B; Van Phan T; Smythe ML; White HF; Oliver SW; et al. Rational Design of Potent Sialidase-Based Inhibitors of Influenza Virus Replication. Nature 1993, 363, 418-423. [PubMed: 8502295]

(16). Kim CU; Lew W; Williams MA; Liu H; Zhang L; Swaminathan S; Bischofberger N; Chen MS; Mendel DB; Tai CY; Laver WG; Stevens RC Influenza Neuraminidase Inhibitors Possessing a Novel Hydrophobic Interaction in the Enzyme Active Site: Design, Synthesis, and Structural Analysis of Carbocyclic Sialic Acid Analogues with Potent Anti-Influenza Activity. J. Am. Chem. Soc 1997, 119, 681-690. [PubMed: 16526129]

(17). von Itzstein M The War Against Influenza: Discovery and Development of Sialidase Inhibitors. Nat. Rev. Drug. Discov 2007, 6, 967-974. [PubMed: 18049471]

(18). Laborda P; Wang SY; Voglmeir J Influenza Neuraminidase Inhibitors: Synthetic Approaches, Derivatives and Biological Activity. Molecules 2016, 21, pii: E1513. [PubMed: 27845731]

(19). Babu YS; Chand P; Bantia S; Kotian P; Dehghani A; El-Kattan Y; Lin TH; Hutchison TL; Elliott AJ; Parker CD; Ananth SL; Horn LL; Laver GW; Montgomery JA BCX-1812 (RWJ-270201): Discovery of A Novel, Highly Potent, Orally Active, and Selective Influenza Neuraminidase Inhibitor Through Structure-Based Drug Design. J. Med. Chem 2000, 43, 3482-3486. [PubMed: 11000002]

(20). Wester A; Shetty AK Peramivir Injection in The Treatment of Acute Influenza: A Review of The Literature. Infect. Drug Resist 2016, 9, 201-214. [PubMed: 27578993]

(21). Yamashita M Laninamivir and Its Prodrug, CS-8958: Long-Acting Neuraminidase Inhibitors for The Treatment of Influenza. Antiviral Chem. Chemother 2010, 21, 71-84. 
(22). Ramos EL; Mitcham JL; Koller TD; Bonavia A; Usner DW; Balaratnam G; Fredlund P; Swiderek KM Efficacy and Safety of Treatment with An Anti-m2e Monoclonal Antibody in Experimental Human Influenza. J. Infect. Dis 2014, 211, 1038-1044. [PubMed: 25281755]

(23). Glanz VY; Myasoedova VA; Grechko AV; Orekhov AN Inhibition of Sialidase Activity as A Therapeutic Approach. Drug. Des. Devel. Ther 2018, 12, 3431-3437.

(24). Slack TJ; Li W; Shi D; McArthur JB; Zhao G; Li Y; Xiao A; Khedri Z; Yu H; Liu Y TriazoleLinked Transition State Analogs as Selective Inhibitors Against V. cholerae Sialidase. Bioorganic Med. Chem 2018, 26, 5751-5757.

(25). Xiao A; Slack TJ; Li Y; Shi D; Yu H; Li W; Liu Y; Chen X Streptococcus pneumoniae Sialidase SpNanB-Catalyzed One-Pot Multienzyme (OPME) Synthesis of 2,7-Anhydro-Sialic Acids as Selective Sialidase Inhibitors. J. Org. Chem 2018, 83, 10798-10804. [PubMed: 30105908]

(26). Khedri Z; Li Y; Cao H; Qu J; Yu H; Muthana MM; Chen X Synthesis of Selective Inhibitors against V. cholerae Sialidase and Human Cytosolic Sialidase NEU2. Org. Biomol. Chem2012,10, 6112-6120. [PubMed: 22641268]

(27). Chen GY; Chen X; King S; Cavassani KA; Cheng J; Zheng X; Cao H; Yu H; Qu J; Fang D; Wu W; Bai XF; Liu JQ; Woodiga SA; Chen C; Sun L; Hogaboam CM; Kunkel SL; Zheng P; Liu Y Amelioration of Sepsis by Inhibiting Sialidase-Mediated Disruption of the CD24-SiglecG Interaction. Nat. Biotechnol 2011, 29, 428-435. [PubMed: 21478876]

(28). Xu G; Li X; Andrew PW; Taylor GL Structure of The Catalytic Domain of Streptococcus pneumoniae Sialidase NanA. Acta. Crystallogr. Sect. F. Struct. Biol. Cryst. Commun 2008, 64, $772-775$.

(29). von Itzstein M Disease-Associated Carbohydrate-Recognising Proteins and Structure-Based Inhibitor Design. Curr. Opin. Struct. Biol 2008, 18, 558-566. [PubMed: 18706999]

(30). Vavricka CJ; Muto C; Hasunuma T; Kimura Y; Araki M; Wu Y; Gao GF; Ohrui H; Izumi M; Kiyota H Synthesis of Sulfo-Sialic Acid Analogues: Potent Neuraminidase Inhibitors in Regards to Anomeric Functionality. Sci. Rep 2017, 7, 8239. [PubMed: 28811524]

(31). Watts AG; Withers SG The Synthesis of Some Mechanistic Probes for Sialic Acid Processing Enzymes and The Labeling of A Sialidase from Trypanosoma rangeli. Can. J. Chem 2004, 82, 1581-1588.

(32). Buchini S; Buschiazzo A; Withers SG A New Generation of Specific Trypanosoma cruzi TransSialidase Inhibitors. Angew. Chem. Int. Ed. Engl 2008, 47, 2700-2703. [PubMed: 18300214]

(33). Buchini S; Gallat FX; Greig IR; Kim JH; Wakatsuki S; Chavas LM; Withers SG Tuning Mechanism-Based Inactivators of Neuraminidases: Mechanistic and Structural Insights. Angew. Chem. Int. Ed. Engl 2014, 53, 3382-3386. [PubMed: 24591206]

(34). Kim J-H; Resende R; Wennekes T; Chen H-M; Bance N; Buchini S; Watts AG; Pilling P; Streltsov VA; Petric M Mechanism-Based Covalent Neuraminidase Inhibitors with BroadSpectrum Influenza Antiviral Activity. Science 2013, 340, 71-75. [PubMed: 23429702]

(35). Delbrouck JA; Chêne LP; Vincent SP, Fluorosugars as Inhibitors of Bacterial Enzymes. In Fluorine in Life Sciences: Pharmaceuticals, Medicinal Diagnostics, and Agrochemicals, Elsevier: 2019; pp 241-279.

(36). Withers S; Rupitz K; Street I 2-Deoxy-2-fluoro-D-glycosyl fluorides. A New Class of Specific Mechanism-Based Glycosidase Inhibitors. J. Biol. Chem 1988, 263, 7929-7932. [PubMed: 3286645]

(37). Amaya MF; Watts AG; Damager I; Wehenkel A; Nguyen T; Buschiazzo A; Paris G; Frasch AC; Withers SG; Alzari PM Structural Insights into the Catalytic Mechanism of Trypanosoma cruzi Trans-Sialidase. Structure 2004, 12, 775-784. [PubMed: 15130470]

(38). Watts AG; Oppezzo P; Withers SG; Alzari PM; Buschiazzo A Structural and Kinetic Analysis of Two Covalent Sialosyl-Enzyme Intermediates on Trypanosoma rangeli Sialidase. J. Biol. Chem 2006, 281, 4149-4155. [PubMed: 16298994]

(39). Newstead SL; Potter JA; Wilson JC; Xu G; Chien CH; Watts AG; Withers SG; Taylor GL The Structure of Clostridium perfringens NanI Sialidase and Its Catalytic Intermediates. J. Biol. Chem 2008, 283, 9080-9088. [PubMed: 18218621] 
(40). Li Y; Cao H; Yu H; Chen Y; Lau K; Qu J; Thon V; Sugiarto G; Chen X Identifying Selective Inhibitors Against The Human Cytosolic Sialidase NEU2 by Substrate Specificity Studies. Mol. Biosyst 2011, 7, 1060-1072. [PubMed: 21206954]

(41). Chokhawala HA; Cao H; Yu H; Chen X Enzymatic Synthesis of Fluorinated Mechanistic Probes for Sialidases and Sialyltransferases. J. Am. Chem. Soc 2007, 129, 10630-10631. [PubMed: 17696347]

(42). Li Y; Yu H; Cao H; Lau K; Muthana S; Tiwari VK; Son B; Chen X Pasteurella multocida Sialic Acid Aldolase: A Promising Biocatalyst. Appl. Microbiol. Biotechnol 2008, 79, 963-970. [PubMed: 18521592]

(43). Yu H; Yu H; Karpel R; Chen X Chemoenzymatic Synthesis of CMP-Sialic Acid Derivatives by A One-Pot Two-Enzyme System: Comparison of Substrate Flexibility of Three Microbial CMPSialic Acid Synthetases. Bioorg. Med. Chem 2004, 12, 6427-6435. [PubMed: 15556760]

(44). Yu H; Chokhawala H; Karpel R; Yu H; Wu B; Zhang J; Zhang Y; Jia Q; Chen X A Multifunctional Pasteurella multocida Sialyltransferase: A Powerful Tool for The Synthesis of Sialoside Libraries. J. Am. Chem. Soc 2005, 127, 17618-17619. [PubMed: 16351087]

(45). Cao H; Li Y; Lau K; Muthana S; Yu H; Cheng J; Chokhawala HA; Sugiarto G; Zhang L; Chen X Sialidase Substrate Specificity Studies Using Chemoenzymatically Synthesized Sialosides Containing C5-Modified Sialic Acids. Org. Biomol. Chem 2009, 7, 5137-5145. [PubMed: 20024109]

(46). Alper PB; Hung S-C; Wong C-H Metal Catalyzed Diazo Transfer for The Synthesis of Azides from Amines. Tetrahedron Lett. 1996, 37, 6029-6032.

(47). Xiao A; Li Y; Li X; Santra A; Yu H; Li W; Chen X Sialidase-Catalyzed One-Pot Multienzyme (OPME) Synthesis of Sialidase Transition-State Analogue Inhibitors. ACS Catal. 2018, 8, 43-47. [PubMed: 29713561]

(48). Tasnima N; Yu H; Li Y; Santra A; Chen X Chemoenzymatic Synthesis of para-Nitrophenol (pNP)-Tagged alpha2-8-Sialosides and High-Throughput Substrate Specificity Studies of alpha2-8-Sialidases. Org. Biomol. Chem 2016, 15, 160-167. [PubMed: 27924345]

(49). Owen CD; Lukacik P; Potter JA; Sleator O; Taylor GL; Walsh MA Streptococcus pneumoniae NanC: Structural Insights into The Specificity and Mechanism of A Sialidase That Produces A Sialidase Inhibitor. J. Biol. Chem 2015, 290, 27736-27748. [PubMed: 26370075]

(50). Xu G; Kiefel MJ; Wilson JC; Andrew PW; Oggioni MR; Taylor GL Three Streptococcus pneumoniae Sialidases: Three Different Products. J. Am. Chem. Soc 2011, 133, 1718-1721. [PubMed: 21244006]

(51). Sela DA; Li Y; Lerno L; Wu S; Marcobal AM; German JB; Chen X; Lebrilla CB; Mills DA An Infant-Associated Bacterial Commensal Utilizes Breast Milk Sialyloligosaccharides. J. Biol. Chem 2011, 286, 11909-11918. [PubMed: 21288901]

(52). Chokhawala HA; Yu H; Chen X High-Throughput Substrate Specificity Studies of Sialidases by Using Chemoenzymatically Synthesized Sialoside Libraries. Chembiochem. 2007, 8, 194-201. [PubMed: 17195254]

(53). Mehr K; Withers SG Mechanisms of The Sialidase and Trans-Sialidase Activities of Bacterial Sialyltransferases from Glycosyltransferase Family 80. Glycobiology. 2016, 26, 353-359. [PubMed: 26582604]

(54). McArthur JB; Yu H; Tasnima N; Lee CM; Fisher AJ; Chen X alpha2-6-Neosialidase: A Sialyltransferase Mutant as a Sialyl Linkage-Specific Sialidase. ACS. Chem. Biol 2018, 13, 1228-1234. [PubMed: 29543427]

(55). Mann MC; Thomson RJ; Dyason JC; McAtamney S; von Itzstein M Modelling, Synthesis And Biological Evaluation of Novel Glucuronide-Based Probes of Vibrio cholerae Sialidase. Bioorg. Med. Chem 2006, 14, 1518-37. [PubMed: 16275104]

(56). Navarro MA; Li J; McClane BA; Morrell E; Beingesser J; Uzal FA NanI Sialidase Is an Important Contributor to Clostridium perfringens Type F Strain F4969 Intestinal Colonization in Mice. Infect. Immun 2018, 86, pii: e00462-18. [PubMed: 30297524]

(57). Mehdizadeh Gohari I; Brefo-Mensah EK; Palmer M; Boerlin P; Prescott JF Sialic Acid Facilitates Binding And Cytotoxic Activity of The Pore-Forming Clostridium perfringens NetF Toxin to Host Cells. PLoS One. 2018, 13, e0206815. [PubMed: 30403719] 


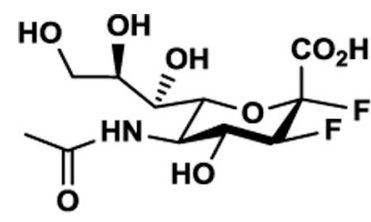
2e3eDFNeu5Ac 1

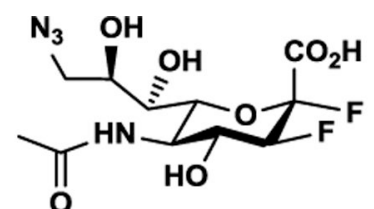

2 e3eDFNeu5Ac9N 3 2

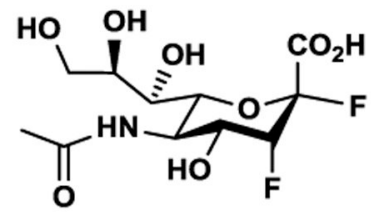

2e3aDFNeu5Ac

5

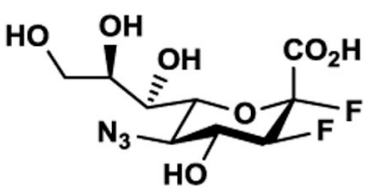

$2 e 3 e D F N e u 5 N_{3}$ 3

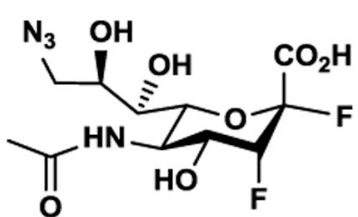

2e3aDFNeu5Ac9N 3

6

Figure 1.

2,3-Difluorosialic acid and analogs synthesized and tested as potential sialidase inhibitors. 

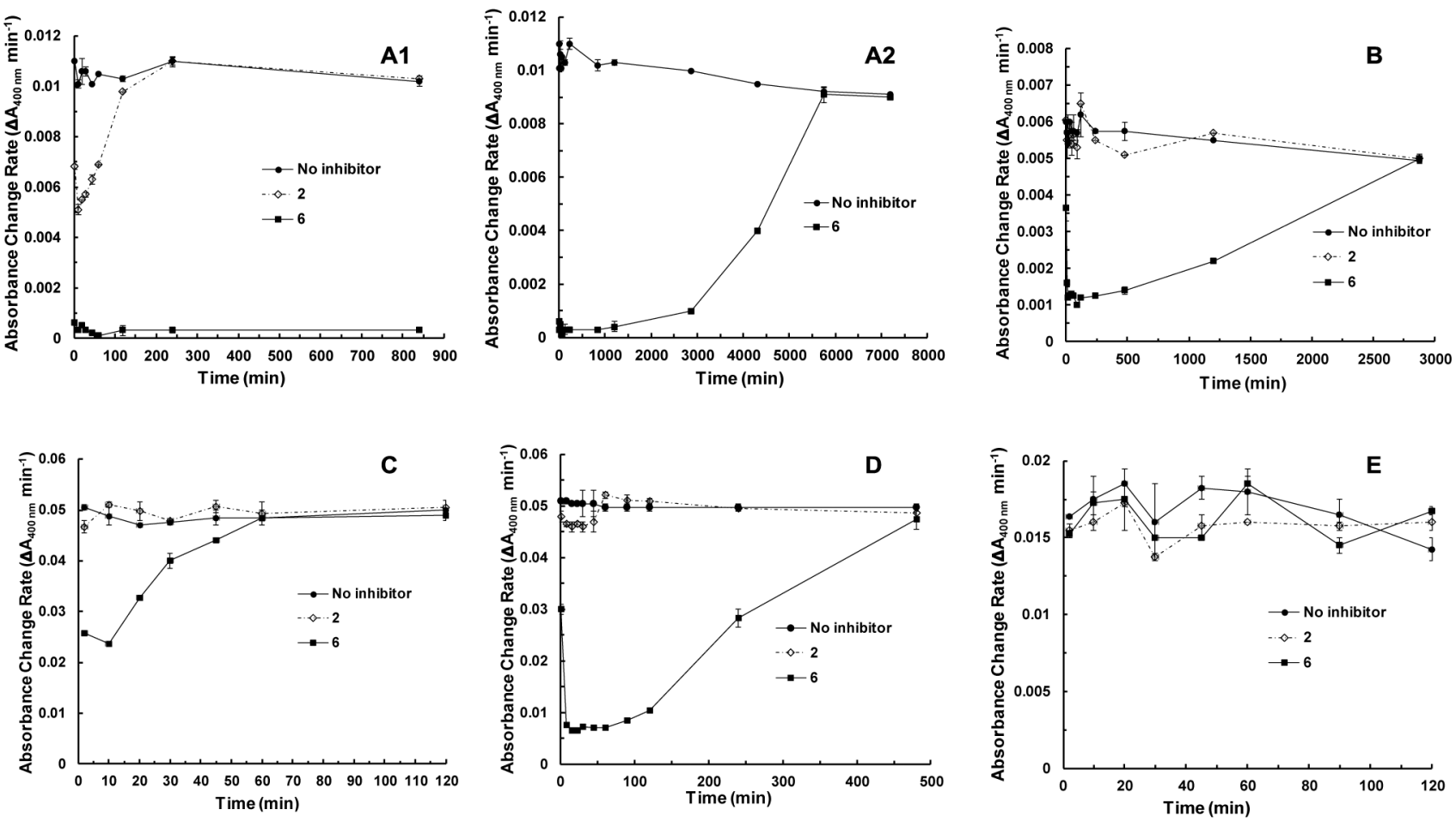

Figure 2.

Time course study results for sialidase de-activation and re-activation in the presence or the absence of a covalent inhibitor ( 2 or 6). A, C. perfringens sialidase CpNanI (A1, 2 min - 14 h for compounds 2 and 6 with no inhibitor as the control; A2, 2 min - 5 days for compound 6 with no inhibitor as the control); B, V. cholerae sialidase; C, SpNanA; D, BiNanH2; E, hNEU2. 


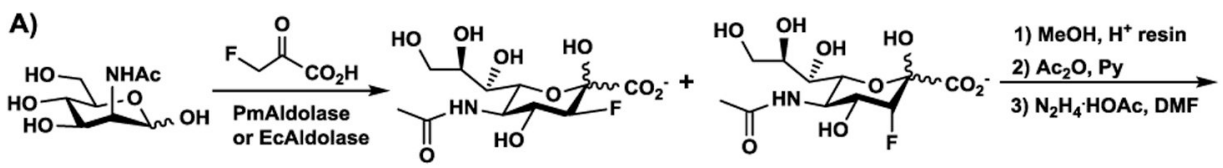

$\begin{array}{lll}7 a, \text { ManNAc } & 8 a, 40 \% & 8 b, 59 \%\end{array}$

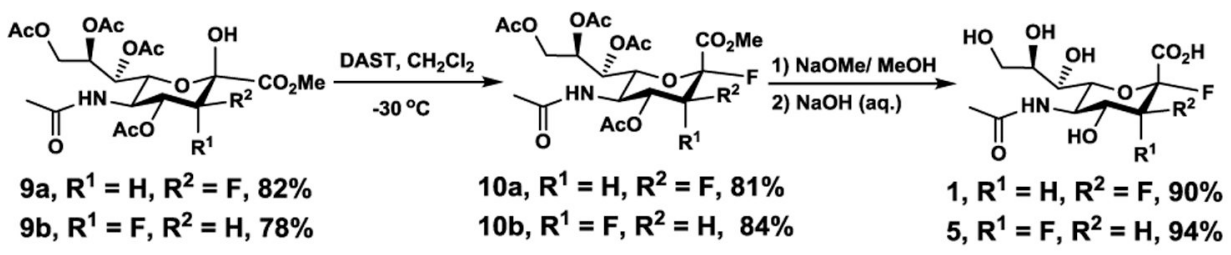

$$
\begin{aligned}
& \text { B) } \\
& \text { 7b, ManNAc6N } 3 \text { 9c, } \mathbf{R}^{1}=\mathrm{H}, \mathbf{R}^{2}=\mathrm{F}, 39 \% \\
& 9 d, R^{1}=F, R^{2}=H, 46 \%
\end{aligned}
$$
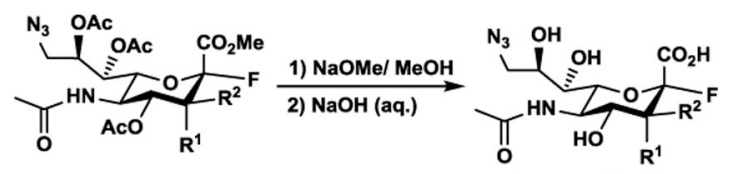

10c, $R^{1}=H, R^{2}=F, 78 \%$

2, $R^{1}=H, R^{2}=F, 83 \%$

10d, $R^{1}=F, R^{2}=H, 74 \%$

$$
6, R^{1}=F, R^{2}=H, 82 \%
$$

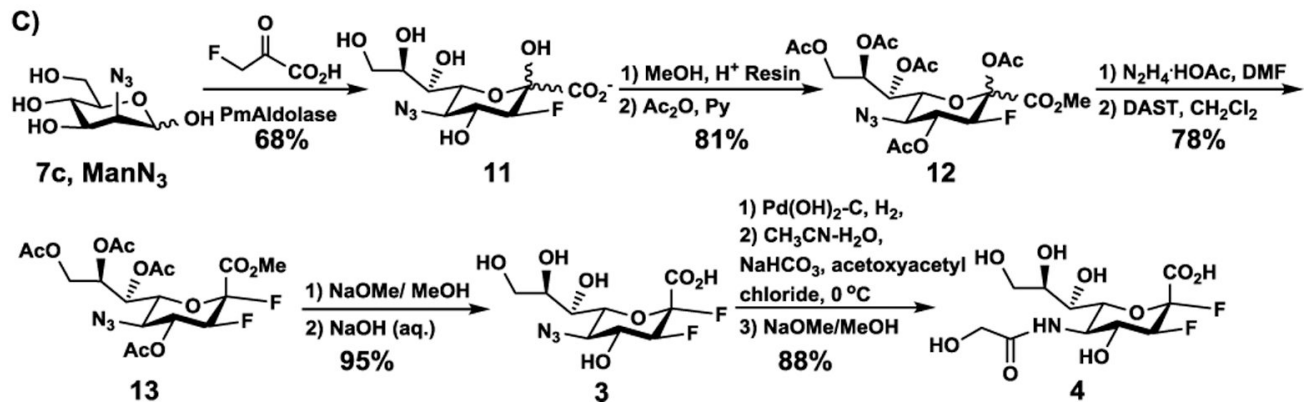

Scheme 1.

Synthesis of 2,3-Difluorosialic Acids and Analogs 1-6. 


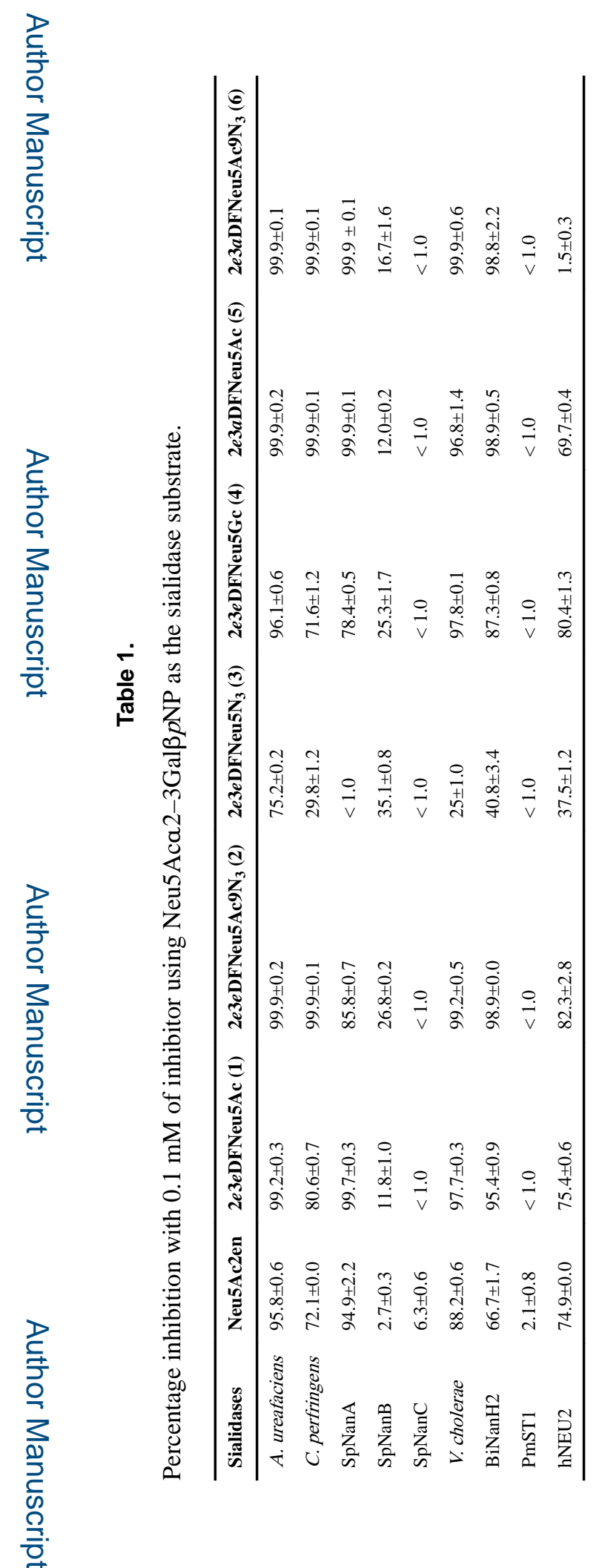

J Org Chem. Author manuscript; available in PMC 2020 June 07. 


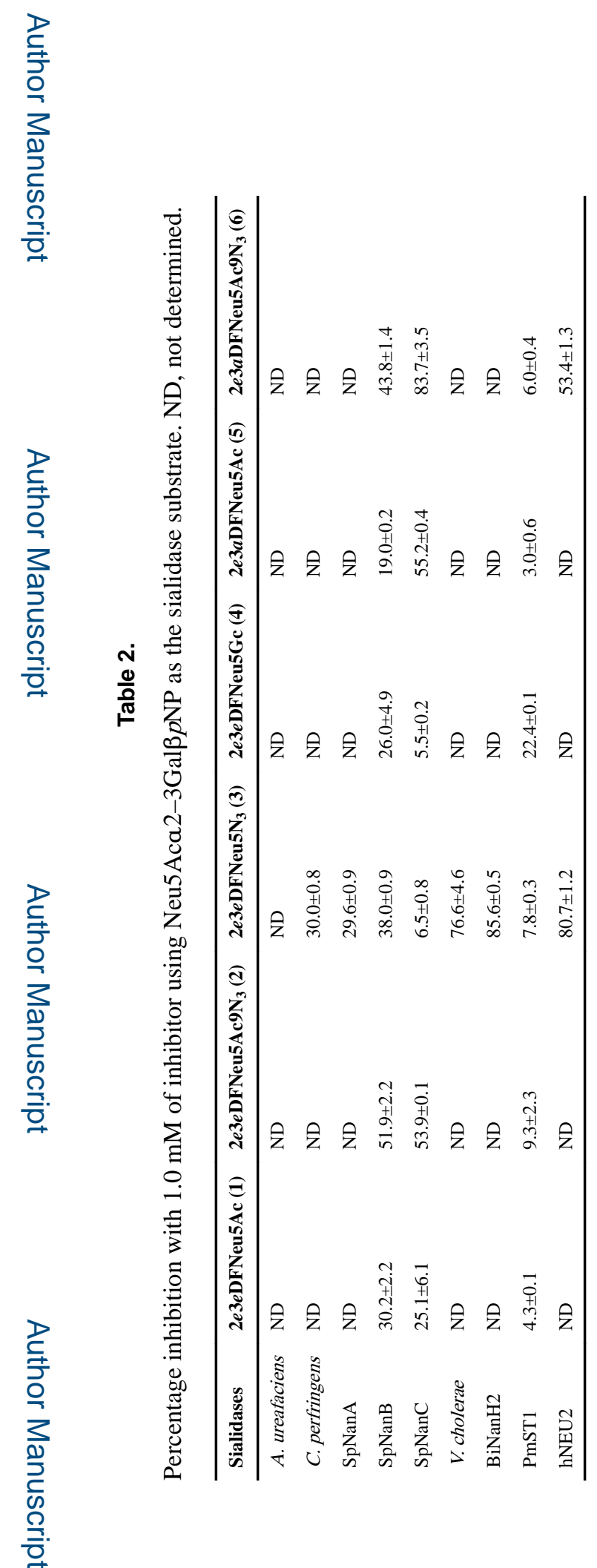

J Org Chem. Author manuscript; available in PMC 2020 June 07. 


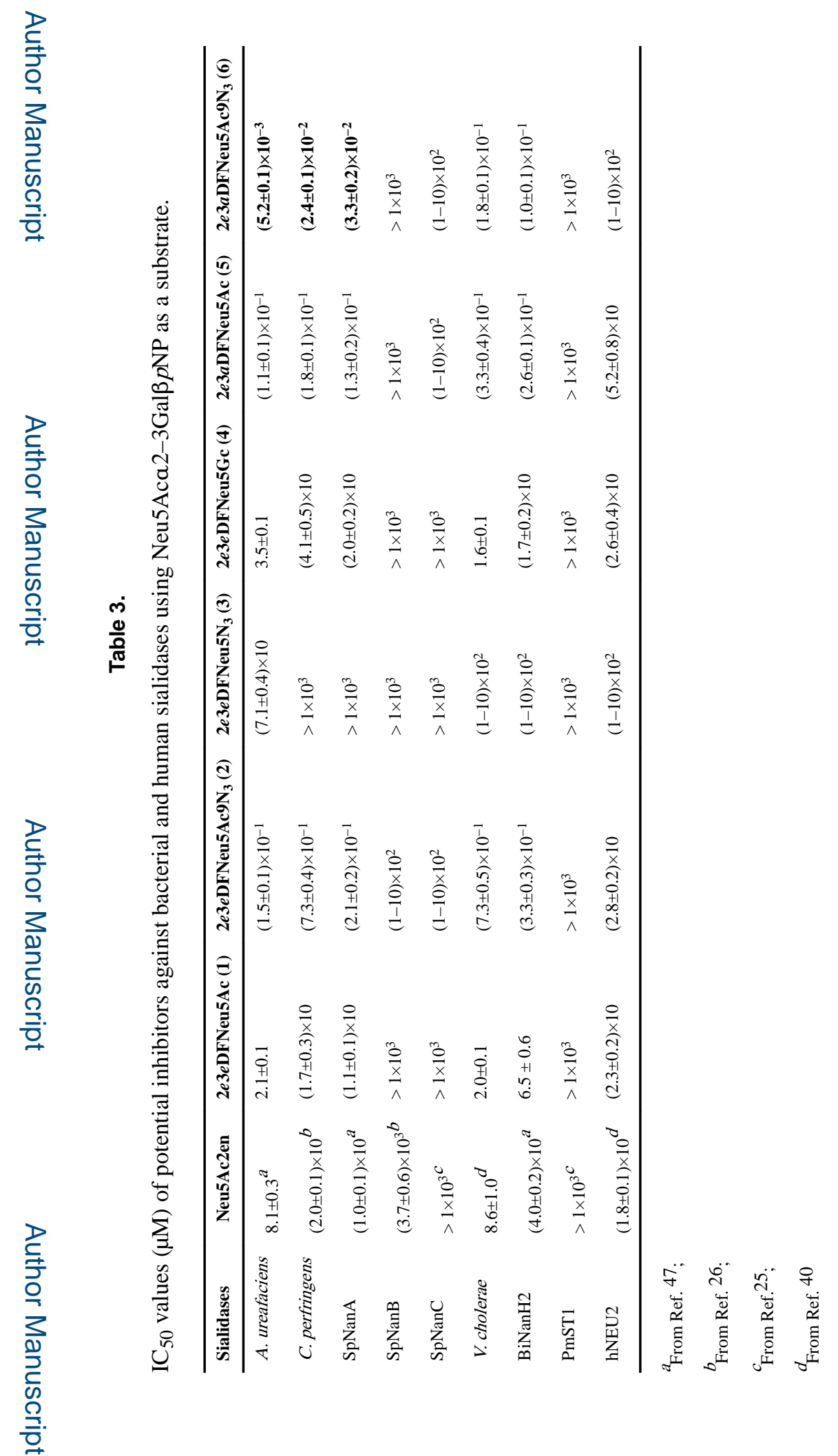

J Org Chem. Author manuscript; available in PMC 2020 June 07. 